\title{
CHITOSAN NANOPARTICLES AS DRUG DELIVERY SYSTEM FOR CEPHALEXIN AND ITS ANTIMICROBIAL ACTIVITY AGAINST MULTIIDRUG RESISTENT BACTERIA
}

\author{
MONA IBRAHIM EL-ASSAL1* ${ }^{*}$ NAGWAN GALAL EL-MENOFY2 \\ 1*Department of Pharmaceutics and Pharmaceutical Technology, Faculty of Pharmaceutical Sciences and Pharmaceutical Industries, \\ Future University in Egypt, 11835, Cairo, Egypt, ${ }^{2}$ Department of Microbiology and Immunology, Faculty of Pharmacy-Girls, Al-Azhar \\ University, 11884, Cairo, Egypt \\ Email: mona.ibrahim@fue.edu.eg
}

Received: 02 Apr 2019 Revised and Accepted: 17 May 2019

\begin{abstract}
Objective: The evolution of antimicrobial resistance is a universal obstacle that necessities the innovation of more effective and safe antimicrobial alternatives with synergistic properties. The purpose of this study was to investigate the possible improvement of cephalexin antimicrobial treatments by loading into chitosan-based nanoparticles, then evaluate their antibacterial and antibiofilm activities as well as determination of its cytotoxicity.
\end{abstract}

Methods: Chitosan nanoparticles (CSNPs) were prepared by ionic gelation method. Parameters were studied to optimize the particle size of CSNPs including $\mathrm{pH}$, stirring rate, homogenization and ultra-sonication time. Size was measured by transmission electron microscope (TEM) and Zeta sizer, morphology seen by scanning electron microscope (SEM). Entrapment efficiency, drug loading and drug content were calculated. Stability of both plain and loaded chitosan Nano-carriers, Drug release and Kinetics also compatibilities were studied. Antimicrobial activity of CSNPs and cephalexin loaded CSNPs were evaluated against $4 \mathrm{Gram}$-positive and $4 \mathrm{Gram}$-negative standard and clinical isolates by microdilution method, also assessment of antibiofilm activity of both formulas was investigated against two biofilm producers clinical isolates by tube assay in addition to determination of their cytotoxicity by MTT(3-(4, 5-dimethylthiazol-2-yl)-2,5-diphenyltetrazolium bromide) assay.

Results: Chitosan nanoparticles and its loaded antibiotics proved compatible combination with small Zeta size, suitable Zeta potential, maximum EE\% and drug-loading capacity, sustained controlled release properties followed diffusion kinetic model and six month stability studies. Cephalexin loaded CSNPs showed better antimicrobial activity than plain CSNPs. Synergistic effects were found against S. aureus (ATCC 25923), B. subtilis (ATCC 9372), S. epidermidis, E. faecalis, P. aeruginosa (ATCC 29853) in addition to two carbapenem resistant isolates $k$. pneumoniae and E. coli. Also cephalexin loaded CSNPs exhibited antibiofilm activity against $E$. faecalis clinical isolate. Even though, cephalexin loaded CSNPs exhibited significant antibacterial activity, it showed less toxicity against mammalian cells, it had IC50 equal to 231.893 and did not exhibit any cytotoxicity against the WI-38 fibroblast cells at concentration $23.4 \mu \mathrm{g} / \mathrm{ml}$.

Conclusion: Cephalexin loaded CSNPs possessed good stability and sustained release effect in addition to its antimicrobial, antibiofilm activities and reduced cytotoxicity.

Keywords: Antimicrobial activity, Antibiofilm, Cephalexin, Chitosan, Cytotoxicity assay, Drug delivery, Nanoparticles

(C) 2019 The Authors. Published by Innovare Academic Sciences Pvt Ltd. This is an open access article under the CC BY license (http://creativecommons.org/licenses/by/4.0/) DOI: http://dx.doi.org/10.22159/ijpps.2019v11i7.33375

\section{INTRODUCTION}

The evolution of microbial resistance against different classes of antibiotic has attracted more attention and forced researchers to formulate innovative antimicrobial agents that exhibit efficient antimicrobial activity against the frequently increasing multidrug resistant pathogens [1]. Limited cellular penetration reduces the effectiveness of many antimicrobial treatments and minimizes its effectiveness against different bacterial infections [2]. Chitosan is a copolymer composed of $\mathrm{N}$-acetyl glucosamine and glucosamine units [3]. It has been used as antibacterial and antifungal material $[4,5]$. There are several mechanisms that explain the antibacterial activity of chitosan, the most acceptable one assumes that chitosan binds to the negatively charged bacterial surface disturbing the cell membrane and altering its permeability then attach to DNA causing inhibition of DNA replication and consequently cell death [6]. Additional probable mechanism is selectively binding of chitosan as chelator to cellular trace elements causing toxicity and growth inhibition [7]. Chitosan exhibit its antibacterial activity only in acidic $\mathrm{pH}$. Several factors affect the antibacterial activity of chitosan including degree of polymerization, molecular weight, chitin type, solvent and $\mathrm{pH}$ of the solution $[8,9]$. Some studies have revealed that chitosan display higher antibacterial activity against Grampositive bacteria more than Gram-negative; meanwhile other studies have reported its higher antibacterial against Gram-negative strains [10]. Cell wall in Gram-positive bacteria composed of thick layer of peptidoglycan polymer with integral protein channels that allow foreign molecules to diffuse into the cell without any difficulty [11, 12]. Conversely, it has been proved that hydrophilicity in Gramnegative bacteria is considerably higher than in Gram-positive bacteria, making them more sensitive to effect of chitosan [13] Moreover chitosan facilitates the transport of molecules across plasma membranes as it is a mucoadhesive polymer [14-16]. Chitosan nanoparticles(CSNPs) provide higher affinity within bacterial cells for a quantum-size effect, due to the larger surface area of the CSNPs, which could be tightly adsorbed onto the surface of the bacterial cells to disrupt the membrane, leading to the leakage of intracellular components and thus bacterial death $[17,18]$. CSNPs have been used a successful drug carriers owing to their transfer efficiency in the cells as reported in several studies [19]. As drug carrier CSNPs offer many advantages as it is biocompatible and biodegradable safe material, available in a wide range of molecular weights, water-soluble polymer [20] has absorption promoting effect that prolongs the contact time between substrate and cell membrane in addition to its diverse non-invasive administration routes as oral, nasal, and ocular rout [21]. Cephalexin is $\beta$-lactam antibiotic that preserves antibacterial activity against both Grampositive and Gram-negative bacteria [22]. It has been efficiently applied in management of bacterial infections in upper and lower respiratory tract, eye and ear, urinary tract, bones and joints as well as skin infection [23]. The aim of the current study was to apply nanotechnology in formulation and delivery of cephalexin as a broad 
spectrum antibiotic and evaluate its antibacterial activity against standard and multidrug resistant strains In addition to study all criteriaof unloaded or loaded nano-carrier with cephalexin, antibiofilm activity and cell toxicity.

\section{MATERIALS AND METHODS}

\section{Mterials}

Chitosan (degree of deacetylation of 93\%) and sodium tripolyphosphate (STPP) were purchased from (Sigma-Aldrich St. Louis, MA, USA). Sodium hydroxide, Methyl alcohol, ethyl alcohol and acetic acid were purchased from El-Nasr Company for chemicals (Cairo, Egypt). And. Cephalexin antibiotic was a gift from Simco Shefa pharmaceutical company (Giza, Egypt). MTT solution was purchased from (Bio Basic Canada Inc, Ontario, Canada). All chemicals were with high quality grade and used without further purification. Mueller-Hinton Agar (MHB), Mueller-Hinton Broth (MHB) and brain heart infusion broth (BHIB) and brain heart infusion agar (BHIA) were obtained from (Lab M Ltd Lancashire, UK). Medium used for cell culturing and cytotoxicity assay was Dulbecco's Modified Eagle's Medium (DMEM) (Thermo Fisher Scientific, Waltham, MA, USA) supplemented with $10 \%$ (v/v) fetal bovine serum (FBS) (Trade Scientific, Sigma-Aldrich, St Louis, MO, USA) in addition to penicillin and streptomycin (100 units $/ \mathrm{ml})$ (Sigma-Aldrich St. Louis, MA, USA).

\section{Bacterial isolates}

Standard bacterial strains obtained from The Egyptian Company for the Production of Sera and Vaccines (VACSERA, Dokki, Giza) and The Regional Center for Mycology and Biotechnology, (Al-Azhar University Cairo, Egypt). and multidrug resistant clinical isolates were selected; they include Staphylococcus aureus (ATCC 25923), Bacillus subtilis (ATCC 9372), Staphylococcusepidermidis and Enterococcus faecalis as representatives for Gram-positive bacteria and Escherichia coli (ATCC 25922), Pseudomonas aeruginosa (ATCC 29853), klebsiella pneumoniae as well as Escherichia coli clinical isolates as representatives for Gramnegative bacteria. Both klebsiella pneumoniae as well as Escherichia coli clinical isolates were identified as carbapenem resistant by phenotypic and molecular method via PCR detection of bla NDM-1 gene that indicates production of metallo-beta-lactamases [24].

\section{Methods}

\section{Preparation of chitosan nanoparticle}

Plain chitosan nanoparticles and cephalexin loaded nanoparticles were prepared based on the modified ionotropic gelation with minor modification $[25,26]$. Chitosan was dissolved in aqueous solution containing $1 \%(\mathrm{v} / \mathrm{v})$ acetic acid and leaving it under high stirring (1100 r/min) for $2 \mathrm{~h}$. The $\mathrm{pH}$ was adjusted to $\mathrm{pH} 5$ with $0.01 \mathrm{~N} \mathrm{NaOH}$. STPP as a physical cross linker was dissolved separately in deionized water and added to the chitosan solution at a drop rate of $12 \mathrm{ml} / \mathrm{h}$ at different STPP: chitosan ratios under vigorous magnetic stirring at room temperature. The resulting suspension was then homogenized at $22000 \mathrm{r} / \mathrm{min}$ for $3 \mathrm{~min}$ and left under ultra-sonication for $45 \mathrm{~min}$.

\section{Preparation of antibiotic-loaded chitosan nanoparticles}

Different concentrations of the antibiotic were used, cephalexinloaded CSNPs were formed spontaneously upon the dropwise addition of an aqueous solution of sodium TPP to $20 \mathrm{ml}$ of a 0.2 $\% \mathrm{w} / \mathrm{v}$ chitosan solutions, containing different five cephalexin concentrations $(0.05,0.1,0.15,0.2$ and $0.25 \% \mathrm{w} / \mathrm{v})$, with constant stirring at high $\mathrm{r} / \mathrm{min}$, followed by homogenization and sonication.

\section{Formula optimization}

\section{Chitosan concentration}

Different chitosan concentrations effect $(0.1,0.15$ and 0.2$) \% \mathrm{w} / \mathrm{v}$ were studied at constant other parameter such as concentration of sodium tri polyphosphate $1 \mathrm{mg} / \mathrm{ml}$ and $\mathrm{pH} 5$,stirring at $1100 \mathrm{r} / \mathrm{min}$, homogenization at $22000 \mathrm{r} / \mathrm{min}$ for $3 \mathrm{~min}$ and ultra-sonication time $45 \mathrm{~min}$ at room temperature.

\section{Sodium tri-poly phosphate concentration}

The effect of concentrations of sodium tri poly phosphate $(0.5,1$, and $1.5) \mathrm{mg} / \mathrm{ml}$ was studied at constant other parameters: concentration of chitosan at $(0.2) \% \mathrm{w} / \mathrm{v}$, at $\mathrm{pH} 5$, stirring at $1100 \mathrm{r} / \mathrm{min}$, homogenization at $22000 \mathrm{r} / \mathrm{min}$ for $3 \mathrm{~min}$ and ultra-sonication time $45 \mathrm{~min}$ at room temperature.

\section{Antibiotic loaded chitosan nanoparticles}

Different cephalexin concentrations loaded in chitosan nanocomposite were studied $(0.05 \% \mathrm{w} / \mathrm{v}, 0.1 \% \mathrm{w} / \mathrm{v}, 0.15 \% \mathrm{w} / \mathrm{v}$, $0.2 \% \mathrm{w} / \mathrm{v}$ and $0.25 \% \mathrm{w} / \mathrm{v}$ ). An optimized formulation was chosen dependent on the set criteria i.e. suitable Nano size, polydispersity (PDI) and maximum entrapment efficiency.

\section{Characterization of chitosan nanoparticles and its loaded}

\section{Differential scanning calorimetric (DSC)}

DSC interactions are typically ascertained as the elimination of endothermic peaks, appearance of recent peaks, difference in peak height and its onset, peak temperature/melting points and relative peak area, or enthalpy. It likewise gives data regarding drug excipient compatibility and development of new substance. Thermal analysis was used in order to elucidate any interactions between cephalexin and investigated polymer. DSC was carried out using Shimadzu, DSC 60 thermal analyzer with a liquid nitrogen cooling accessory. The analysis was performed under purge of dry nitrogen gas $\left(40 \mathrm{~mL} / \mathrm{min}^{-1}\right)$. A sample of $2-5 \mathrm{mg}$ was placed in an aluminum crucible cell and was firmly crimped with the lid to provide an adequate seal. The samples were heated from ambient temperature to $400 \mathrm{C}{ }^{\circ}$ at a preprogrammed heating rate of $10 \mathrm{C} \% \mathrm{~min}^{-1}$. All samples were analyzed in the same manner.

\section{Fourier transform infrared analysis}

FTIR is used to study the molecular interaction between formulation components. The infrared spectrum of previously lyophilized cephalexin CSNPs sample was studied. FTIR spectra of the chitosan, STPP, free cephalexin, physical mixture and lyophilized cephalexin CSNPs were recorded by using an FT-IR spectrophotometer (Nexus 670 , Nicolet, USA) in the region of $4000-400 \mathrm{~cm}^{-1}$ with spectra resolution of $4 \mathrm{~cm}^{-1}$.

\section{Optical microscopy}

A thin layer of formed colloidal dispersion were spread on a slide, diluted with a small drop of deionized water then dried. The nature of vesicle observed and the presence of drug crystals which are insoluble were focused under light microscope at various magnification powers $(10 \times a n d 40 \times)$. Photomicrographs were taken using Fujifilm Finepix F 40 fd (8.3 MP) digital camera with $3 \times$ optical zoom. [25].

\section{Size analysis and zeta potential}

The particle size and polydispersity index of formulated CSNPs either drug loaded or unloaded was determined by using Zeta sizer by dynamic light scattering (Nano ZS, Malvern, and Worcester-shire, UK). The ionic potential at the partcles surface called Zeta potential, and it is measured in millivolts. Zeta potential is a logical term for electro kinetic potential in colloidal dispersions and it is the most imperative parameter for physical stability of CSNPs. The higher the electrostatic repulsion between the particles more is the stability [26]. Before measurement samples were dispersed in distilled water. Three replicates were measured and values were presented as mean \pm standard deviation (SD).

\section{Transmission electron microscope}

The morphology and size of the prepared CSNPs formulations was investigated by transmission electron microscopy (TEM) HU-12A (Hitachi Ltd, Mito, Japan) at the Research Park of Faculty of Agriculture, Cairo University. A drop of the dispersion was diluted 10 -fold using deionized water, and then a drop of the diluted dispersion was applied to a carbon-coated 300 mesh copper grid and left for $1 \mathrm{~min}$ to allow some of the CSNPs to adhere to the carbon substrate. The remaining dispersion was removed by absorbing the 
drop with the corner of a piece of filter paper. After twice rinsing the grid with deionized water for (3-5 s) a drop of $2 \%$ aqueous solution of uranyl acetate was applied for $1 \mathrm{~s}$. The remaining solution was removed by absorbing the liquid with the tip of a piefelttef paper and the sample was air dried [27].

\section{Scanning electron microscope}

Scanning electron microscopy (SEM) (Hitachi-S 3400N) was performed at the Center of Agriculture Researches, Cairo University. It was used to study visualization that provides surface morphology and basic composition of sample by emitting electrons [28]. The samples were mounted directly onto the SEM using double sided sticking tape and were gold spray coated [29].

\section{Cephalexin loading and encapsulation efficiencies}

The encapsulation and loading efficiencies of the nanoparticles were determined by first separating the nanoparticles from the aqueous medium by ultracentrifugation at $15,000 \mathrm{r} / \mathrm{min}$ for $30 \mathrm{~min}$ at $4 \mathrm{C}$ ${ }^{\circ}$ (Sigma,3-30KS,Germany), A standard calibration curve of drug was plotted for this purpose. The amount of free cephalexin in the supernatant was measured using a UV spectrophotometer at $257 \mathrm{~nm}$ (Shimadzu-UV/800, Japan). The encapsulation efficiencies \% of the nanoparticles and cephalexin loading \% were calculated as follows:

Encapsulation efficiency $\%=\mathrm{T}_{\mathrm{P}}-\mathrm{T}_{\mathrm{f}} / \mathrm{T}_{\mathrm{P}} \times 100$ (1)

Where $\mathrm{Tp}$ is the total cephalexin used to prepare the nanoparticles and $\mathrm{T}_{\mathrm{f}}$ is the free cephalexin in the supernatant.

Loading efficiency $\%=T_{P}-T_{f} /$ Mass of nanoparticles X 100 (2)

\section{Drug content}

Drug content was determined thrice at weeks 4, 8 and 12 from first date of preparation by placing each lyophilized dried formula after weighing in $20 \mathrm{ml}$ phosphate buffered saline $\mathrm{pH}$ 6.8, followed by agitation in an incubator shaker $(100 \mathrm{r} / \mathrm{min})$ for $24 \mathrm{~h}$ at $37 \mathrm{C}^{\circ}$. After suitable dilutions drug solubilized was analyzed spectrophotometrically at $\lambda \max 257 \mathrm{~nm}$.

\section{Release of cephalexin from CSNPs nanocomposites}

The in vitro release refers to the rate of dissolving the drug from an intact dosage form fragments or particles. There are two reasons for performing in vitro release tests, one of them is to ensure product uniformity from batch to batch, and the other reason is to predict the rate of drug absorption and/or availability of the drug for absorption. In vitro release is more fundamental important than disintegration for predicting in vitro drug availability [30]. The in vitro release studies of cephalexin loaded CSNPs were carried out in USP type II auto sampler dissolution apparatus (Hansen, Germany) fitted with eight rotating paddle and vessels. Five concentrations formulas were used for release study; the medium employed was $600 \mathrm{ml}$ of $\mathrm{HCl}, \mathrm{pH} 1.2$ for $2 \mathrm{~h}$ then changed to phosphate buffer $\mathrm{pH}$ 6.8 at $37^{\circ} \mathrm{C}+0.5^{\circ} \mathrm{C}$. by adding $30 \mathrm{gm}$ of Tri-sodium orthophosphate [31], each concentration was repeated thrice. The paddle speed was $100 \mathrm{r} / \mathrm{min}$. At appropriate intervals $(0.5,1,1.5$ and $2 \mathrm{~h})$ at $\mathrm{HCl} \mathrm{pH} \mathrm{1.2,}$ $(0,0.5,1,1.5,2,2.5,3,3.5,4,4.5,5,6,8,10,12,14,16,18,20,22$, and $24 \mathrm{~h}$ ) at phosphate buffer $\mathrm{pH} 6.8,2 \mathrm{ml}$ of each sample was taken and replaced by fresh dissolution media. The samples were analyzed at $257 \mathrm{~nm}$ by UV-visible spectrophotometer.

\section{Kinetics of antibiotic's release}

In order to know the mechanism of drug release from the CSNPs, the experimental cumulative release data were fitted on various release model commonly used to describe the release kinetics from nanoparticles such as First order, second order, Higuchi kinetic models, Hixson-Crowell kinetic models, diffusion and Baker model at $\mathrm{pH} 1.2$, and 6.8 using multiple linear regression analysis (sigma plot 11 software). The release rate constant $(\mathrm{K})$ and correlation coefficient $\left(\mathrm{r}^{2}\right)$ close to unity was taken as order of release. The following models were fitted: log cumulative \% drug remaining versus time (first order kinetic model), log concentrations plot versus time is a straight line with $\mathrm{k}$ equal slope of the line (second order kinetic model), cumulative $\%$ drug release versus square root of time (Higuchi model), cube root of the initial concentration minus cube root of percent remaining versus time (Hixson-Crowell models), the release rate constant, $k$, corresponds to the slope and drug release studies were plotted as [d $(\mathrm{Mt} / \mathrm{M} \infty)] / \mathrm{dt}$ with respect to the root of time inverse. (Baker Lonsdale) [32].

\section{Stability study}

Both plain and loaded CSNPs were stability studied. By keeping the optimum unloaded formula of CSNPs as cephalexin carriers at two different temperature conditions like refrigeration temperature $(4 \mathrm{C}$ $\left.{ }^{\circ}\right)$, room temperature $\left(25 \pm 2 \mathrm{C}^{\circ}\right)$ in aluminum foil sealed glass vials. The samples were withdrawn at different time intervals over a period of six month and they were observed visually and under optical microscope and examined morphologically by TEM for the change in consistency and appearance of drug crystals upon storage. Also Nano size, PDI and Zeta potential were examined [25]. The mean particle size of CSNPs loaded dispersion, surface charge (Zeta potential) and PDI was determined by using a Malvern zeta sizer (Malvern Instruments, UK) on the spot and monthly for six month. The stability of vesicles to retain the drug was assessed, the retention of entrapped drug of $0.25 \% \mathrm{w} / \mathrm{v}$ loaded CSNPs formula was measured $72 \mathrm{~h}$ after preparation and then monthly of 6 mo duration [33]. Stability for formulation was deined in terms of retaining its initial entrapment fefiency for six months duration. Stable formulation was dfined by showing high entrapment efficiency $(>60 \%)$ and high drug retention value $(>90 \%)$ at each time interval, also non-significant change in size, PDI and Zeta potential. Drug retained in CSNPs= Entrapped Cephalexin after storage/Entrapped Cephalexin before storage $\times 100$.

\section{In vitro evaluation of antibacterial activity}

The antibacterial activity of CSNPs $(1250 \mu \mathrm{g} / \mathrm{ml})$ and cephalexin $(250$ $\mu \mathrm{g} / \mathrm{ml}$ ) loaded CSNPs $1250 \mu \mathrm{g} / \mathrm{ml}$ ) were carried out by microdilution method for determination of minimal inhibitory concentration (MIC) then determination of minimum bactericidal concentration (MBC) and compared to cephalexin $(1000 \mu \mathrm{g} / \mathrm{ml})$ as the reference antibiotic. The protocol of the studies (REC-FPSPI-11/72) was approved by the Research Ethics Committee for experimental and microbiological studies at the Faculty of Pharmaceutical Sciences and Pharmaceutical Industries, Future University in Egypt.

\section{Assessment of minimum inhibitory concentration (mic) and minimum bactericidal concentration (MBC)}

The MIC was detected by broth microdilution method according to Novy et al. [34] with minor modifications. Briefly, 100 [2 of MHB was transferred to each well in 96 microplate then serial two-fold dilution with CSNPs, cephalexin loaded CSNPs and cephalexin. Then, 5 Q $\mathrm{L}$ of a fresh bacterial culture (final concentration of $1 \times 108 \mathrm{CFU} / \mathrm{ml}$ ) of tested microorganism was added. Positive and negative control wells (without drugs and bacterial culture respectively) were processed along. Microplates were incubated at $37^{\circ} \mathrm{C}$ for $24 \mathrm{~h}$. The experiment was performed in triplicate. MIC was defined as the lowest concentration of the formula that inhibits the visible growth of tested microorganism. For determination of MBC, 100 ? $\mathrm{L}$ from each well that showed no visible growth was inoculated on MHA agar plates; then the plates were incubated at $37 \circ \mathrm{C}$ for $24 \mathrm{~h}$. MBC was defined as the lowest concentration showing no bacterial growth on agar surfaces.

The synergy of antibacterial activity is usually expressed by sum of Fractional Inhibitory Concentration (FIC) by the following formula:

$$
\begin{aligned}
\text { FIC (cephalexin) } & =\frac{\text { MIC ofcephalexin loaded in CSNPS }}{\text { MIC of cephalexin }} \text { FIC (CSNPs) } \\
& =\frac{\text { MIC ofCSNPs load cephalexin }}{\text { MIC of CSNPS }}
\end{aligned}
$$

$\Sigma$ FIC=FIC of cephalexin+FIC of CSNPs [35].

The results were interpretted as follow; a synergistic effect when $\Sigma$ FIC value $<1$; a commutative effect when $\Sigma$ FICvalue $=1$; an indifferent effect when $1<\Sigma$ FIC value $\leq 2$ and an antagonistic effect when $\Sigma$ FIC value $>2$ [36].

\section{Antibiofilm assay}

At first, production of biofilm formation for tested microorganisims was detected by inoculation on congo red agar (CRA) (BHI agar 
supplemented with $5 \%$ sucrose and $0.8 \%$ congo red). A single colony of all tested bacteria were culturd overnight in the medium for $24 \mathrm{~h}$ at $37^{\circ} \mathrm{C}$. The plates were inspected for color of the colonies. Positive biofilm producers were indicated by black colonies with a dry crystalline consistency while non biofilm producers strains formed red colonies.

Antibiofilm assay was performed by tube method according to Hasan et al.[37], with a slight modification. Briefly $2 \mathrm{ml}$ of sterilized (BHI) media was added to sterilized narrow and small test tubes. Then, $50 \mu \mathrm{l}$ of a fresh culture of selected strains (final concentration of $1 \times 10^{8} \mathrm{CFU} / \mathrm{ml}$ ) was added to each. Sub MIC concenterations of cephalexin loaded CSNPs and CSNPs were inoculated to each tube. Negative and positive controls tubes were processed for each strain then all tubes were incubated at $37^{\circ} \mathrm{C}$ for $24 \mathrm{~h}$. The formation of biofilm in all test tubes was examined at $24 \mathrm{~h}$ interval. the tubes were decanted and washed with normal saline and dried followed by staining with $0.1 \%$ crystal violet then the contents were decanted gently. Excess stain was washed with distilled water and dried. Biofilm formation was considered positive when visible film lined the wall and bottom of the tube. Ring formation at the air liquid interface was not indicative of biofilm formation.

\section{Cell Culturing and MTT cytotoxicity assay}

A MTT (3-(4, 5-dimethylthiazol-2-yl)-2,5-diphenyltetrazolium bromide) assay was performed to determine the cytotoxic effects of CSNPs and cephalexin loaded CSNPs on the WI-38 cells (human normal embryonic lung-derived fibroblasts) were purchased from the ATCC (American Type Culture Collection, CCL- $75^{\mathrm{m}}$ ). A 96 well tissue culture plate was inoculated with 1 X $10^{5} \mathrm{WI}-38$ cells $/ \mathrm{ml}(100$ $\mu \mathrm{l} /$ well) and incubated at $37^{\circ} \mathrm{C}$ in supplemented DMEM media to develop a complete monolayer sheet. Growth medium was decanted from 96 well micro titer plates after confluent sheet of cells was formed; cell monolayer was washed twice with wash media. Serial two-fold dilutions of CSNPs and cephalexin loaded CSNPs were made in DMEM media with 2\% FBS (maintenance medium). After that 0.1 $\mathrm{ml}$ of each dilution was tested in different wells leaving 3 wells as control, receiving only maintenance medium. Plate was incubated for $24 \mathrm{~h}$ at $37^{\circ} \mathrm{C}$ and examined. Cells were checked under inverted microscope for any physical signs of toxicity, e. g. partial or complete loss of the monolayer, rounding, shrinkage, or cell granulation. MTT solution was prepared ( $5 \mathrm{mg} / \mathrm{ml}$ in phosphate buffer saline) then 20 $\mu \mathrm{l}$ of MTT solution were added to each well. The plate was placed on a shaking table (150 rpm for $5 \mathrm{~min}$ ) to thoroughly mix the MTT into the media and incubated at $37^{\circ} \mathrm{C}$ in $5 \% \mathrm{CO}_{2}$ for $1-5 \mathrm{~h}$ to allow MTT to metabolize. The media were dumped off then the plate was dried on paper towels to remove any residue. Formazan (MTT metabolic product) was re-suspended in $200 \mu \mathrm{l}$ DMSO and placed on a shaking table (150 rpm for $5 \mathrm{~min}$ ) to thoroughly mix the formazan with the solvent. Optical density was measured at $560 \mathrm{~nm}$ using a multiwall microplate reader (Synergy HT, BioTek, France,) and background was subtracted at $620 \mathrm{~nm}$. Optical density is directly correlated with cell quantity. The experiment was performed in triplicate, and the result is expressed as the mean \pm SD [38].

$$
\text { Cell viability } \%=\frac{\text { Average of treated }}{\text { Average control }} \times 100
$$

\section{RESULTS AND DISCUSSION}

Preparation and Characterization of Chitosan Nanoparticles
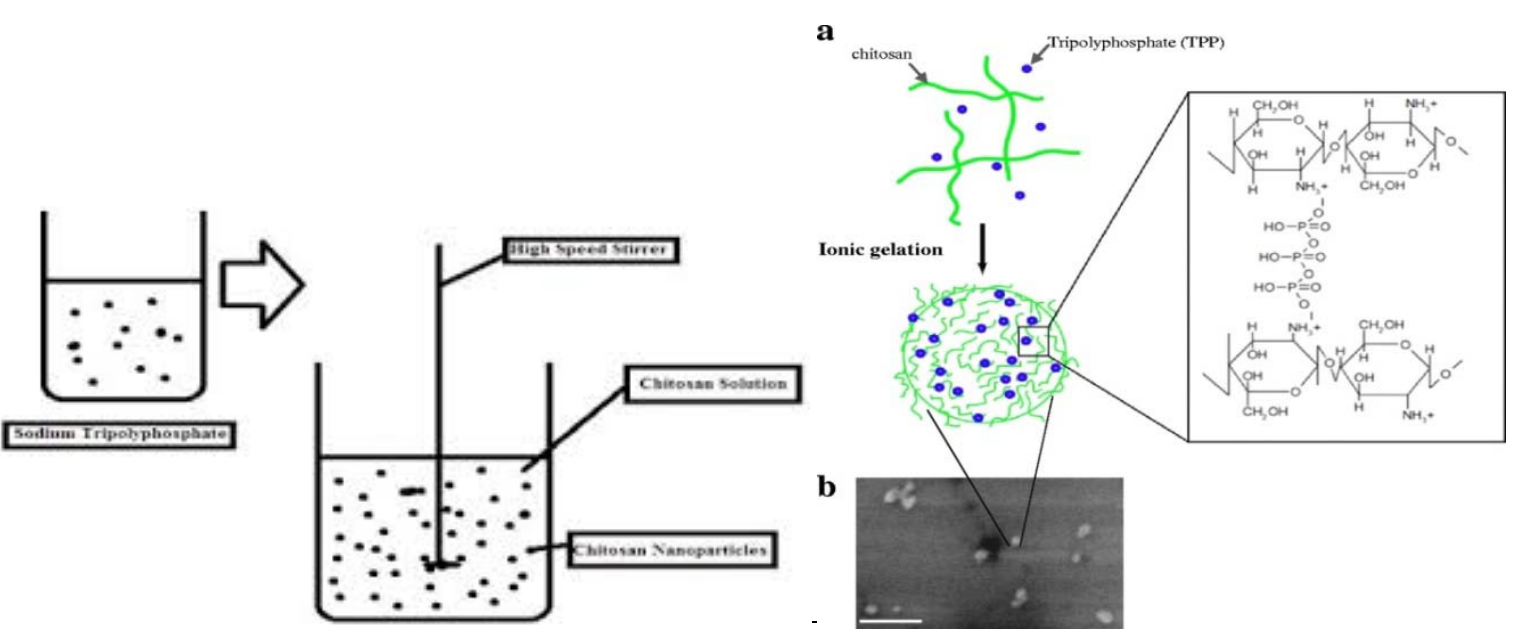

Fig. 1: Formation of the chitosan-tripolyphosphate complex by ionotropic gelation. (a) Schematic illustration of the chitosan-STPP complex and (b) TEM image of chitosan nanoparticles with $35 \mathrm{~nm}$ diameter

\section{Effect of chitosan concentration on nanoparticles size}

By studying the chitosan concentration effect $(0.1,0.15$ and 0.2$) \%$ $\mathrm{w} / \mathrm{v}$, while constant other parameter such as concentration of sodium tri polyphosphate $1 \mathrm{mg} / \mathrm{ml}$ and $\mathrm{pH} \mathrm{5,1100} \mathrm{r/min} \mathrm{stirrer}$ rate, $22000 \mathrm{r} / \mathrm{min}$ homogenization for $3 \mathrm{~min}$ and ultra-sonication time $45 \mathrm{~min}$., It was observed that with increase in the concentration of chitosan the appearance of the solution changed from clear viscous liquid to opalescent fluid and then precipitated the solution became opalescent indicating the formation of Nano chitosan with smallest Nano size ranged $(23-35 \mathrm{~nm})$. From table 1 it is obvious that by increasing the chitosan concentration from 0.1 to $0.2 \% \mathrm{w} / \mathrm{v}$ at a constant STPP concentration $(1 \mathrm{mg} / \mathrm{ml})$, the size of nanoparticles measured by TEM were decrease. Nano sizes of particles are more favorable at the chitosan concentration of 0.2 $\% \mathrm{w} / \mathrm{v}$ was $(23-35 \mathrm{~nm})$ with mean of $33.6 \pm 17.9$ than $0.15 \% \mathrm{w} / \mathrm{v}$ (34$71 \mathrm{~nm}$ ) with mean of $40.2 \pm 25.5$ and $0.1 \% \mathrm{w} / \mathrm{v}(43-95 \mathrm{~nm})$ with mean of $38.1 \pm 15.4$.

Table 1: Effects of different chitosan concentrations on Nano-carriers optimization $(n=3)$ parameters

\begin{tabular}{lllll}
\hline CS conc. \%w/v & TEM size d. $\mathbf{~} m$ & Malvern Zeta sizer d. $\mathbf{~ n m}$ & PDI & Zeta potential \pm SD $\mathbf{~} V$ \\
\hline 0.1 & $38.109 \pm 15.439$ & $222.8 \pm 99.752$ & $0.236 \pm 0.026$ & $13.366 \pm 0.152$ \\
0.15 & $40.271 \pm 25.526$ & $203.733 \pm 42.700$ & $0.299 \pm 0.074$ & $17.233 \pm 2.490$ \\
0.2 & $33.632 \pm 17.966$ & $176.633 \pm 69.933$ & $0.280 \pm 0.080$ & $17.833 \pm 4.282$ \\
\hline
\end{tabular}

$\mathrm{n}=$ number of determination; $\mathrm{SD}=$ Standard Deviation 


\section{Effect of STPP concentration on nanoparticles size}

The effect of concentration of sodium tri poly phosphate $(0.05,1$ and $1.5) \mathrm{mg} / \mathrm{ml}$ was studied at constant other parameters: concentration of chitosan at $(0.2) \% \mathrm{w} / \mathrm{v}$, at $\mathrm{pH}(5), 1100 \mathrm{r} / \mathrm{min}$ stirrer rate, 22000 $\mathrm{r} / \mathrm{min}$ homogenization for $3 \mathrm{~min}$ and ultra-sonication time $45 \mathrm{~min}$. Sodium tri poly phosphate (STPP) a major ingredient for cross linking has a pronounced effect on the properties of chitosan dispersion, the concentration of STPP was increased gradually, the solution became opalescent indicating the formation of Nano chitosan. It was observed from table 2 that with increase in concentration of STPP, the particle size of chitosan nanoparticle increased measured by TEM, concentration of STPP above $1 \mathrm{mg} / \mathrm{ml}$ resulted precipitation. The precipitation at excessively higher concentration of STPP may be attributed to the aggregation of chitosan molecules due to excessive cross linking through STPP bridging. By increasing the STPP concentration from 0.5 to $1.5 \mathrm{~g} / \mathrm{ml}$ at a constant chitosan concentration $(0.2 \% \mathrm{w} / \mathrm{v})$, the mean size of chitosan nanoparticles changed from $8.4 \pm 2.6 \mathrm{~nm}$ at $(0.5 \mathrm{mg} / \mathrm{ml})$ to $39.3 \pm 14.8 \mathrm{~nm}$ at $(1.5 \mathrm{mg} / \mathrm{ml})$ but the more favorable mean size was $15.4 \pm 12.8 \mathrm{~nm}$ at $(1 \mathrm{mg} / \mathrm{ml})$ of STPP which have a good distribution for a nanoparticle all over the solution i.e. mean PDI was $0.27 \pm 0.008$.

Table 2: Effects of different STPP concentrations on Nano-carriers optimization parameters $(n=3)$

\begin{tabular}{|c|c|c|c|c|}
\hline STPP conc. $\mathrm{mg} / \mathrm{ml}$ & TEM size d. $\mathrm{nm}$ & Malvern Zeta sizer d. nm & PDI & Zetapotential \pm SD mV \\
\hline 0.5 & $8.417 \pm 2.669$ & $252.3 \pm 126.496$ & $0.315 \pm 0.070$ & $24.1 \pm 5.392$ \\
\hline 1 & $15.433 \pm 12.879$ & $157 \pm 17.578$ & $0.276 \pm 0.008$ & $18.266 \pm 1.474$ \\
\hline 1.5 & $39.341 \pm 14.811$ & $475.8 \pm 79.870$ & $0.402 \pm 0.167$ & $10.876 \pm 2.935$ \\
\hline
\end{tabular}

$\mathrm{n}=$ number of determination; $\mathrm{SD}=$ Standard Deviation

\section{Effect of cephalexin concentrations}

Ionotropic gelation was successfully preparing CSNPs; this technique relies on the interaction between negatively charged polyanions and positively charged chitosan polymer to form covalently cross-linked networks. Table 3 clarify the effect of cephalexin concentrations on Nano carries, the mean size distribution was vary according to $\% \mathrm{w} / \mathrm{v}$ antibiotic loaded. The mean size measured by Malvern Zeta sizer was $194.7 \pm 33.5 \mathrm{~nm}$ with $0.05 \% \mathrm{w} / \mathrm{v}, 200.7 \pm 36.2 \mathrm{~nm}$ with $0.1 \% \mathrm{w} / \mathrm{v}, 307.1 \pm 39.5 \mathrm{~nm}$ with 0.15
$\% \mathrm{w} / \mathrm{v}, 205.7 \pm 24.1 \mathrm{~nm}$ with $0.2 \% \mathrm{w} / \mathrm{v}$ and $218.5 \pm 83.8 \mathrm{~nm}$ with 0.25 $\% \mathrm{w} / \mathrm{v}$ with a fairly monodisperse polydispersity index which almost 0.2. Nanoparticles carried a positive charge zeta potential ranged between $17.3 \pm 3.6$ to $21.3 \pm 3.3 \mathrm{mV}$. Drug Encapsulation efficiency percent was high with all loading $\% \mathrm{w} / \mathrm{v}$ ranged from $89.714 \pm 2.231 \%$ to $95.305 \pm 2.013 \%$. Drug loading \% was increased by increasing loading $\% \mathrm{w} / \mathrm{v}$. Drug loading was $12.930 \pm 0.236 \%$ with $0.05 \%$ w/v loading, $23.294 \pm 1.071 \%$ with $0.1 \% \mathrm{w} / \mathrm{v}, 29.915 \pm 0.910 \%$ with $0.15 \% \mathrm{w} / \mathrm{v}, 37.156 \pm 0.436 \%$ with $0.2 \% \mathrm{w} / \mathrm{v}$ and $43.32 \pm 0.914 \%$ with $0.25 \% \mathrm{w} / \mathrm{v}$.

Table 3: Effects of different Cephalexin concentrations on Nano-carriers optimization $(n=3)$ parameters

\begin{tabular}{lllll}
\hline Drug conc. \%w/v & Malvern zeta sizer d. nm & PDI & Zeta potential \pm SD mV & EE\% drug loading \% \\
\hline 0.05 & $194.766 \pm 33.526$ & $0.366 \pm 0.085$ & $18.1 \pm 4.828$ & $90.517 \pm 1.66012 .930 \pm 0.236$ \\
0.1 & $200.74 \pm 36.260$ & $0.284 \pm 0.043$ & $19.575 \pm 5.429$ & $92.699 \pm 3.67423 .294 \pm 1.071$ \\
0.15 & $307.125 \pm 39.519$ & $0.306 \pm 0.070$ & $21.3 \pm 3.329$ & $89.714 \pm 2.23129 .915 \pm 0.910$ \\
0.2 & $205.7 \pm 24.153$ & $0.268 \pm 0.025$ & $18.133 \pm 2.345$ & $92.892 \pm 1.09037 .156 \pm 0.436$ \\
0.25 & $218.5 \pm 83.815$ & $0.207 \pm 0.030$ & $17.333 \pm 3.650$ & $95.305 \pm 2.01343 .32 \pm 0.914$ \\
\hline
\end{tabular}

$\mathrm{n}=$ number of determination; $\mathrm{SD}=$ Standard Deviation

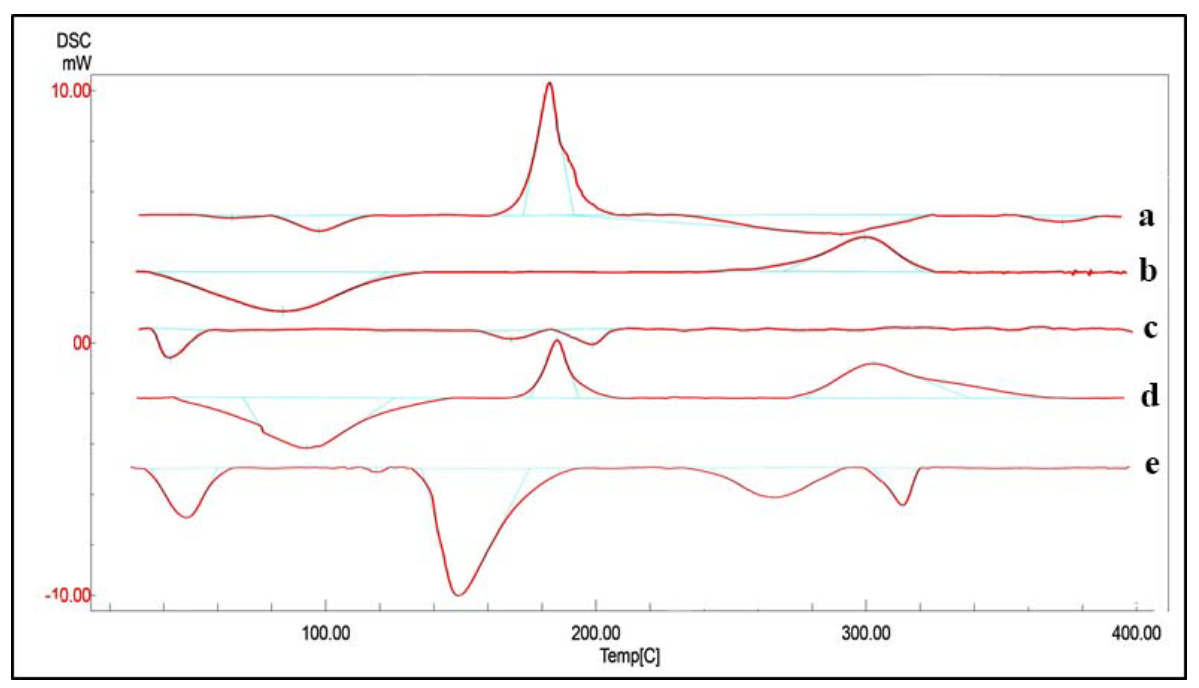

Fig. 2: DSC Thermogram, (a) cephalexin, (b) Chitosan, (c) STPP, (d) physical mixture, (e) cephalexin-CSNPs nanocomposite

\section{Differential scanning calorimetric (DSC)}

As shown in fig. 2, DSC heat flux versus temperature curve for cephalexin showed a broad endothermic melting process at $103^{\circ} \mathrm{C}$, while a sharp positive exothermic transition beak around $188.44^{\circ} \mathrm{C}$.
Broad endothermic beak at $296.52{ }^{\circ} \mathrm{C}$ was indicating cephalexin decomposition. Endothermic peak at $87.51{ }^{\circ} \mathrm{C}$ was indicating glass transition temperature of chitosan and dehydration, while exothermic peak at $303.19{ }^{\circ} \mathrm{C}$ was indicating polymer degradation. STPP have 
melting temperature at $42.90{ }^{\circ} \mathrm{C}$ was shown by endothermic peak. Clear glass transition endothermic peak was observed at $199.73{ }^{\circ} \mathrm{C}$. The physical mixture shows similar peaks support physical compatibility. The water-holding capacity of cross-linked chitosan with STPP at $\mathrm{pH} 5$ was found to be more $(\Delta \mathrm{H} 439.56 \mathrm{~J} / \mathrm{g})$ compared with that of plain chitosan, the cross-linking of chitosan with STPP modifies the crystalline nature of chitosan. The hydrophilicity of crosslinked chitosan is higher at $\mathrm{pH} 5$, which might be responsible for its increase in the water holding capacity. On the basis of these results it can be stated that increase in the polar groups and reduction in crystalline domains caused an increase in the water-holding capacity of cross-linked chitosan. These results are in agreement with the work done by Kittur et al. [39], where they studied the thermal behavior of chitosan and their carboxymethyl derivatives showing that the increase in the $\mathrm{N}$-deacetylation and carboxymethylation of chitosan led to increase in the water-holding capacity. Owing to the differences in the chemical characteristics, changes in the exothermic peak of chitosan and cross-linked chitosan were also observed. The presence of free unsubstituted amine groups showed higher $\Delta \mathrm{H}$ values. As the free amine groups in cross-linked chitosan with STPP at $\mathrm{pH} 5$ are more, the $\Delta \mathrm{H}$ value found was $31.11 \mathrm{~J} / \mathrm{g}$, the energy required was $19.50 \mathrm{~J} / \mathrm{g}$. Characterization of cross-linked chitosan by DSC provided the evidence of reduction in crystallinity and increase in hydrophilicity after cross-linking with STPP pH 5.

\section{Zeta potential}

Zeta potential is identified with the charge on the surface of the molecule, thus impacts an extensive range of properties of colloidal materials, for example, their stability, interaction with electrolytes and suspension rheology. Literature suggested that zeta potential value should lie in the range of $-20 \mathrm{mV}$ to $+30 \mathrm{mV}$. Zeta potential was found to be ranged from $10.876 \pm 2.935 \mathrm{mV}$ to $24.1 \pm 5.392 \mathrm{mV}$ that indicates the formation of stable formulation. In general positive Zeta potential values of CSNPs, due to carboxyl group of chitosan.

\section{FTIR}

The FTIR spectra are shown in fig. 3. The spectrum obtained for cephalexin monohydrate sample shows major bands at $3414 \mathrm{~cm}^{-1}$, $3275 \mathrm{~cm}^{-1}, 2607 \mathrm{~cm}^{-1}, 1758 \mathrm{~cm}^{-1}, 1689 \mathrm{~cm}^{-1}$ and $1593 \mathrm{~cm}^{-1}$, similar to that reported by Di Stefano et al. [40]. When compared with the standard cephalexin monohydrate (PSA), the capsule (CCC), the raw powder (PMD) and the suspension ample (CSM) had the same FTIR profile although CSM was amorphous. The broad band at $\sim 2600 \mathrm{~cm}^{-}$ 1 due to stretching mode of $\mathrm{NH}^{3+}$ confirming the presence of Zwitterionic form. Chitosan showed characteristic peaks in IR spectrum which confirms its saccharide structure. These peaks are obtained at 1153,1384, 1616, and $894 \mathrm{~cm}^{-1}$. Characteristic strong amino peak was found at around $3545 \mathrm{~cm}^{-1}, 2360 \mathrm{~cm}^{-1}$ and $2017 \mathrm{~cm}-$ ${ }^{1}$ which are assigned to amide I and II bands. The peak at $1990 \mathrm{~cm}^{-1}$ in $\mathrm{C} 3$ is the joint contribution of bend vibration of $\mathrm{OH}$ and $\mathrm{CH}$. The free aldehyde group absorption appearing at $1616 \mathrm{~cm}^{-1}$, chitosan hydrogen bonded hydroxyl group gave a peak at $3417 \mathrm{~cm}^{-1}$. The broadness of the peak is due to presence of water and subsequent hydrogen bonding. For STPP, the peak between 1091 and $1215 \mathrm{~cm}^{-1}$ region refers to $\mathrm{PO}$ gr oup present in phosphate [41]. The peak at $1095 \mathrm{~cm}^{-1}$, on the other hand, could be attributed to P-O-R vibration of the phosphate group. The FTIR spectra of chitosan and crosslinked chitosan are shown in fig. 3, a characteristic band at $3429 \mathrm{~cm}^{-}$ ${ }^{1}$ is attributed to- $\mathrm{NH} 2$ and-OH groups stretching vibration and the band for amide I at $1616 \mathrm{~cm}^{-1}$ is seen in the infrared spectrum of chitosan. Whereas in the FTIR spectra of cross-linked chitosan the peak of $1616 \mathrm{~cm}^{-1}$ disappears and 2 new peaks at $1639 \mathrm{~cm}^{-1}$ and $1562 \mathrm{~cm}^{-1}$ appears. The disappearance of the band could be attributed to the linkage between the phosphoric and ammonium ions. The crosslinked chitosan also showed a peak for $\mathrm{P}=0$ at 1384 $\mathrm{cm}^{-1}$. Some researchers [42-44], observed similar results in their study of formation of chitosan nanoparticles and chitosan film treated with phosphate.

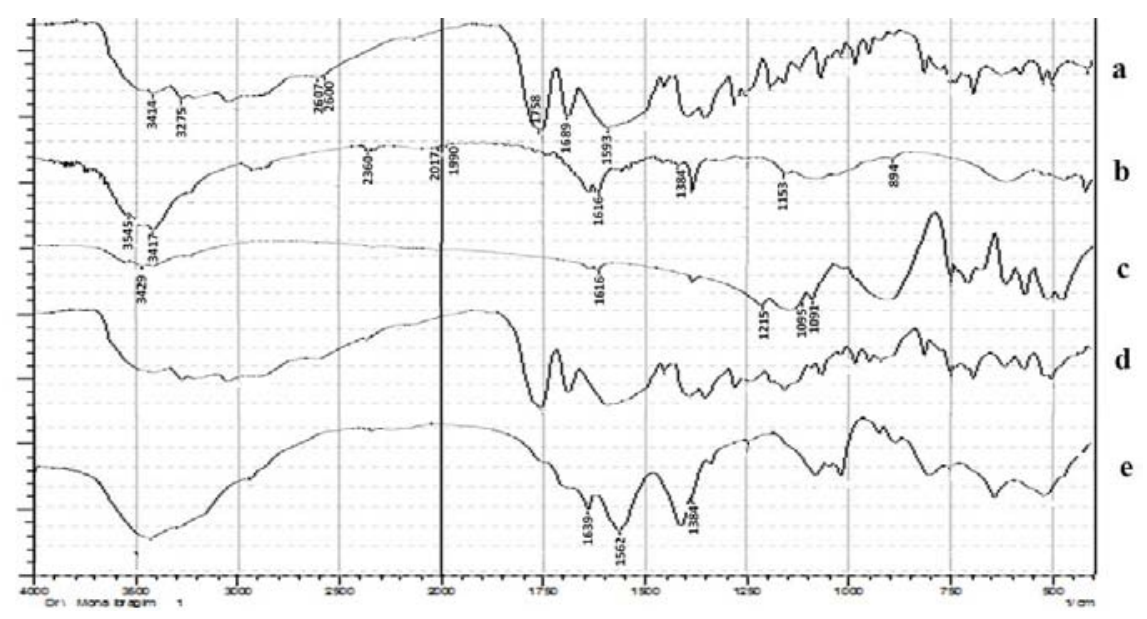

Fig. 3: FTIR Diagram, (a) cephalexin, (b) Chitosan, (c) STPP, (d) physical mixture, (e) cephalexin-CSNPs nanocomposite

\section{Optical microscopy}

Examination of both plane and loaded CSNPs with different antibiotic concentrations $\% \mathrm{w} / \mathrm{v}$, were showed small vesicles with uniform surface area fig. 4 a. shown vesicles of optimized chitosan (CS) Nano-carriers loaded with $0.25 \% \mathrm{w} / \mathrm{v}$.

\section{Size analysis}

The size of nanoparticles could be varied by changing the chitosan concentrations $\% \mathrm{w} / \mathrm{v}$. Measuring Nano diameter by Zeta sizer was $222.8 \pm 99.7 \mathrm{~d}$. nm with CS $0.1 \% \mathrm{w} / \mathrm{v}, 203.7 \pm 42.7 \mathrm{~d}$. nm with CS $0.15 \%$ $\mathrm{w} / \mathrm{v}$ and $176.6 \pm 69.9 \mathrm{~d}$. nm with CS $0.2 \% \mathrm{w} / \mathrm{v}$. Polydispersity index was 0.2 and Zeta potential ranged from $13.3 \pm 0.1 \mathrm{mV}$ to $17.8 \pm 4.2 \mathrm{mV}$ as shown in table 1. Changing the amount of STPP sequencing Nano size diameter was changed, it was $252.3 \pm 126.4 \mathrm{~d}$. $\mathrm{nm}$ with $0.5 \mathrm{mg} / \mathrm{ml}$ cross linker concentration, $157 \pm 17.5 \mathrm{~d}$. nm with $1 \mathrm{mg} / \mathrm{ml}$ and $475.8 \pm 79.8 \mathrm{~d}$. $\mathrm{nm}$ with $1.5 \mathrm{mg} / \mathrm{ml}$ STPP. Polydispersity index was ranged from to 0.2 to 0.4 and Zeta potential ranged from $10.8 \pm 2.9 \mathrm{mV}$ to $24.1 \pm 5.3 \mathrm{mV}$ as shown in table 2. Different \%w/v of cephalexin loaded changing Nano size as was explained and shown in table 3. Average vesicle's size of CSNPs measured by Zeta sizer was found to be higher than measuring with TEM. This is may be attributed to the difference in the principles underlying these techniques.

\section{Transmission electron microscope}

Fig. 4 showed TEM image indicate homogenous small-sized Nano spherical structures with smooth morphology. The unloaded Nano particles also exhibited rigid surface with higher reliability, due to the interfacial interaction between STPP and polymer chain. The average diameter of plane CSNPs with different CS concentrations are ranged from $33.632 \pm 17.966 \mathrm{~nm}$ to $40.271 \pm 25.526 \mathrm{~nm}$. Nanocarriers with different STPP concentrations ranged in diameter from $8.417 \pm 2.669 \mathrm{~nm}$ to $39.341 \pm 14.811 \mathrm{~nm}$. The TEM image is in good agreement with that in the literature. 


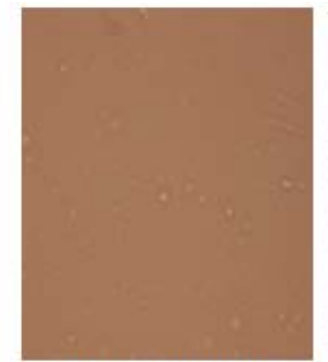

a- Optical microscopy

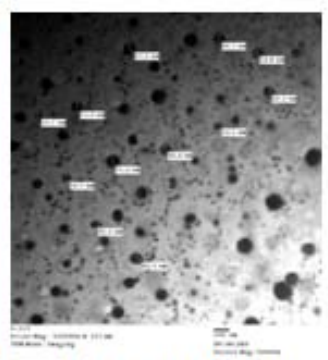

b- CS $0.1 \% \mathrm{w} / \mathrm{v}$

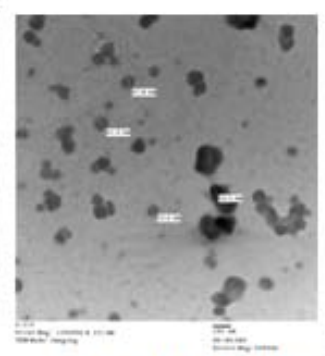

c- CS $0.15 \%$ w/v

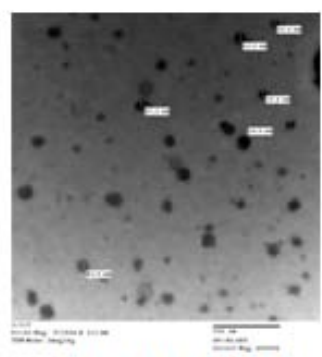

d-CS $0.25 \% W / V$

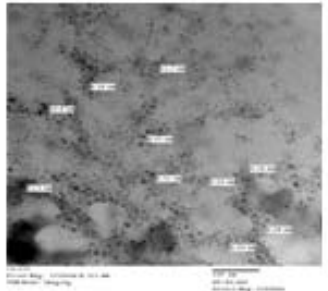

e- STPP 0.5MG/ML

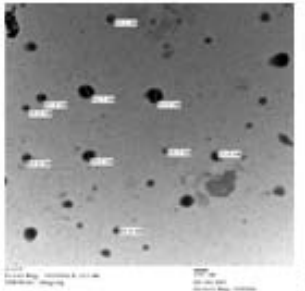

f- STPP $1 \mathrm{mg} / \mathrm{ml}$

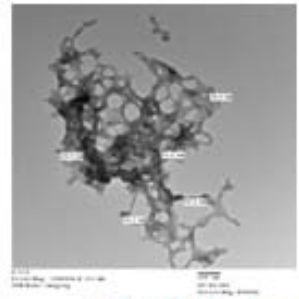

j- STPP $1.5 \mathrm{mg} / \mathrm{ml}$

Fig. 4: a. optical view of loaded vesicles. $b, c$ and $d$ TEM image of unloaded vesicles with different CS concentrations, $e, f$ and $j$ TEM image of unloaded vesicles with different STPP concentrations
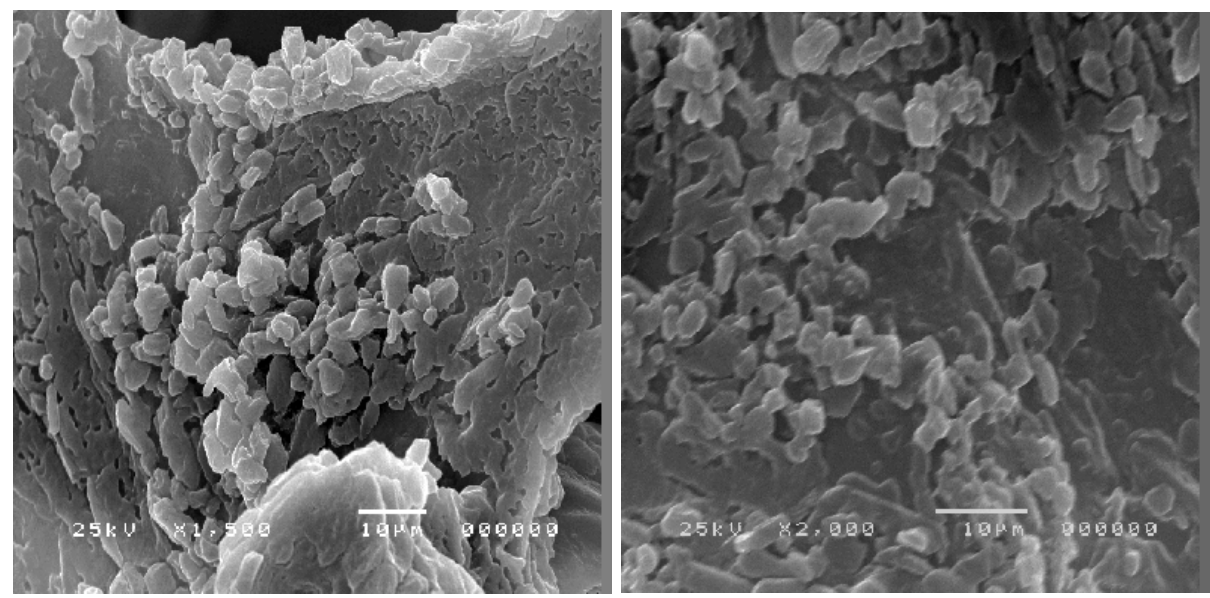

Fig. 5: SEM image of cephalexin-CSNPs nanocomposite

\section{Scanning electron microscope}

The surface morphology of the lyophilized dried cephalexin-CSNPs nanocomposite, as studied by field-emission scanning electron microscopy, is shown in fig. 5. The nanocomposites appear to have an agglomerated structure with a non-uniform size. This aggregation could be a result of the strong inter-and intra-molecular hydrogen bonding between nanoparticles.

\section{Cephalexin loading and encapsulation efficiencies \%}

Percentage encapsulation efficiency was measured by "centrifuge method", in which unentrapped drug was calculated spectrophotometrically. All loaded antibiotic formulations gave excellent percentage entrapment efficiency as shown in table 3. EE\% was $90.517 \pm 1.660$ for $0.05 \% \mathrm{w} / \mathrm{v}$ loaded antibiotic, $92.699 \pm 3.674$ for $0.1 \% \mathrm{w} / \mathrm{v}, 89.714 \pm 2.231$ for $0.15 \%, 92.892 \pm 1.090$ for $0.2 \% \mathrm{w} / \mathrm{v}$ and $95.305 \pm 2.013$ for $0.25 \% \mathrm{w} / \mathrm{v}$. Zeta size, PDI, Zeta potential and $\%$ drug loading were measured for each drug loading.

\section{Drug content}

Each of the studied three samples was loaded with $0.25 \% \mathrm{w} / \mathrm{v}$ antibiotic and showed high drug content. At week 4 drug contents was $96.35 \%$, at week 8 it was $96.24 \%$ and at week 12 drug contents was $96.27 \%$ with average equal to $96.289 \%$. The predominant influencing factor could be good percent entrapment efficiency, narrow size distribution of the prepared nanoparticles and the nanoparticles were fairly stable.

\section{Release of cephalexin from CSNPs nanocomposites}

Fig. 6 presents cephalexin \% release profile up to $26 \mathrm{~h}$. The CSNPs showed initial releases of cephalexin in acidic medium $\mathrm{pH} 1.2$ ranging from 20 up to $40 \%$ for all concentrations were used in the release study. This initial release of cephalexin was forced by some antibiotic localized on the surface of CSNPs by adsorption and could be released easily by diffusion. After this initial effect, a slower sustained and controlled release occurred throughout the release period at $\mathrm{pH} 6.8$, and the release amount was $100 \%$ in both $0.2 \% \mathrm{w} / \mathrm{v}$ and $0.25 \% \mathrm{w} / \mathrm{v}$ loaded cephalexin at $20 \mathrm{~h}$. Other loaded concentrations as $0.05 \% \mathrm{w} / \mathrm{v}, 0.1 \% \mathrm{w} / \mathrm{v}$ and $0.15 \% \mathrm{w} / \mathrm{v}$ their release at $26 \mathrm{~h}$ were $38 \%, 50 \%$ and $66 \%$ respectively. The release profiles indicated that cephalexin molecules were encapsulated among the positively charged chitosan chains, also high antibiotic loaded concentrations in CSNPs reflect accepted complete release during $26 \mathrm{~h}$. 


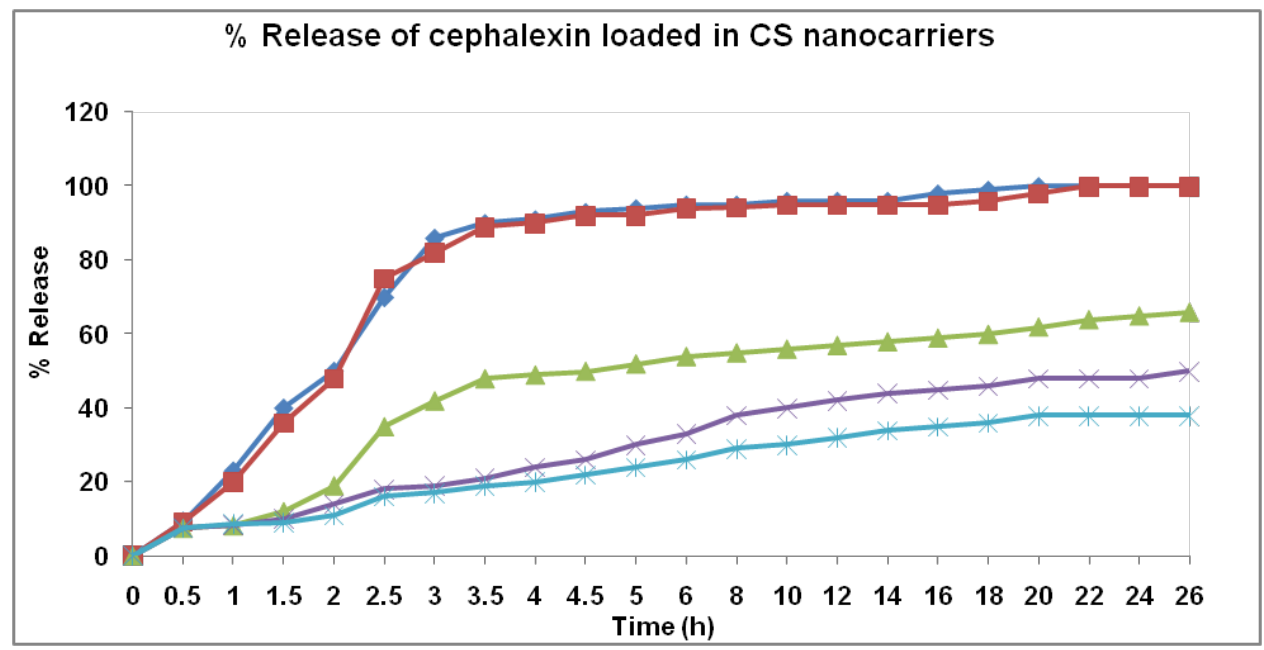

Fig. 6: \% Release of cephalexin loaded in CS nano carriers ( $n=3$; mean \pm SD)

\section{Release kinetics study}

The data of the release of the cephalexin from the nanocomposites were fitted to six kinetic models, which are described as shown in table 4 . The results indicated that the release of most antibiotic concentrations from the nanocomposites followed diffusion kinetic model, with a best fit value for the correlation coefficient (R2) at 0.9761 . The rate of drug release from any solid or semi-solid delivery system is usually controlled by dissolution and/or diffusion. Regardless of mechanisms involved in the release, its rate under sink conditions can be expressed by a single general equation as follows:

$$
\frac{d w}{d t}=\frac{D}{h} S C_{s}
$$

$\mathrm{W}$ is amount of drug released up to time $\mathrm{t}$ and $\mathrm{dw} / \mathrm{dt}$ is the rate of release. D, S, Cs and $h$ are drug molecule diffusion coefficient, effective surface area of drug with release medium, drug solubility in the medium and the length of diffusion path. This equation represents both the Noyes-Whitney law of dissolution [45], applied for dissolution rate limited release as well as the Fick's first law of diffusion used for diffusion rate limited release processes [46]. In the dissolution process $h$, the thickness of stagnant aqueous layer around drug particle is constant but $S$ and sometimes D are varied during the release process [47]. On the other hand in a diffusion rate limited release in addition to $\mathrm{D}, \mathrm{h}$ and sometimes $\mathrm{S}$ are variable during the release process. For a complex system such as nanoparticles the previous equation does not seem to include all other factors influencing the release rate among which penetration rate of liquid into the system; hydration, swelling, relaxation, erosion and dissolution of polymer can be mentioned. The extents of liquid penetration and the polymer contributed properties are directly proportional to $t 1 / 2$ and powered of $t$, respectively. Thus, these effects are collectively represented as a time dependent variable, $\mathrm{X}$, and the equation becomes:

$$
\frac{d w}{d t}=\frac{D}{\boldsymbol{h}} S C_{s} X
$$

Therefore, regardless of release mechanism in order to obtain a general working formula for both dissolution and diffusion rate limited release processes it is assumed that the term DSX/h is variable during the release.

Table 4: Data fitting for cephalexin release from cephalexin-CSNPs using six different

\begin{tabular}{lllllll}
\hline & Zero & First & Second & Diffusion & Hixon & Baker \\
\hline $\mathrm{a}$ & 13.66772 & 1.725437 & 0.010341 & 1.360582 & 0.217743 & 0.002237 \\
$\mathrm{~b}$ & 0.030174 & $3.8 \mathrm{E}-05$ & $7.75 \mathrm{E}-06$ & 1.393847 & 0.000599 & $3.97 \mathrm{E}-05$ \\
$\mathrm{r}$ & 0.906972 & 0.043844 & 0.816441 & 0.976108 & 0.927012 & 0.973077 \\
$\mathrm{k}$ & 0.030174 & $8.75 \mathrm{E}-05$ & $7.75 \mathrm{E}-06$ & 1.393847 & 0.000599 & $3.97 \mathrm{E}-05$ \\
$\mathrm{t}(1 / 2)$ & 45 & 7920.455 & 1290.394 & 1286.796 & 1595.407 & 1387.085 \\
\hline
\end{tabular}

\begin{tabular}{|c|c|c|c|c|c|}
\hline Optimum formula & \multicolumn{2}{|c|}{ at $25^{\circ} \mathrm{C}$} & \multicolumn{2}{|c|}{ at $4^{\circ} \mathrm{C}$} & \\
\hline TEM size & \multicolumn{2}{|c|}{$55.2 \pm 12.4$} & \multicolumn{2}{|c|}{$30 \pm 15.1$} & \\
\hline Zeta size & \multicolumn{2}{|c|}{$287 \pm 81.156$} & \multicolumn{2}{|c|}{$184.36 \pm 25.276$} & \\
\hline PDI & \multicolumn{2}{|c|}{$0.311 \pm 0.103$} & \multicolumn{2}{|c|}{$0.297 \pm 0.052$} & \\
\hline Zeta potential \pm SD & \multicolumn{2}{|c|}{$20.05 \pm 2.317$} & \multicolumn{2}{|c|}{$18.174 \pm 5.379$} & \\
\hline Optimum-loaded formula & mo 1 mo 2 & mo 3 & mo 4 mo5 & mo6 & mean \pm SD \\
\hline TEM size & 42.646 .2 & 50.1 & 49.455 .5 & 54.3 & $49.7 \pm 4.8$ \\
\hline Zeta size & 205.9216 .8 & 204.5 & 233242.1 & 245.5 & $224.633 \pm 18.0$ \\
\hline PDI & 0.2160 .341 & 0.284 & 0.3820 .341 & 0.332 & $0.349 \pm 0.04$ \\
\hline Zeta potential & 24.724 .1 & 22 & 17.518 .6 & 20.2 & $19.516 \pm 3.3$ \\
\hline $\mathrm{EE} \%$ & 93.53192 .685 & 94.429 & 96.66395 .315 & 95.421 & $94.674 \pm 1.4$ \\
\hline Drug loading & 43.52142 .192 & 42.921 & 43.93743 .9 & 42.8 & $43.061 \pm 0.6$ \\
\hline Retention value \% & 10099.095 & 98.313 & 96.22396 .00 & 96.00 & $97.605 \pm 1.7$ \\
\hline
\end{tabular}

Table 5: Six month stability studies of optimized unloaded nano-carriers at different temperature

Six month stability studies of Nano-carriers loaded with cephalexin $0.25 \% \mathrm{w} / \mathrm{v}$

All data presented as mean \pm SD 


\section{Stability study of cephalexin CSNPs}

Table 5 clarify the optimized plane formula measured monthly for six month at two different temperature. The average Nano size at $25 \mathrm{C}^{\circ}$ was $287 \pm 81.156 \mathrm{~nm}$, and that at $4 \mathrm{C}^{\circ}$ was $184.36 \pm 25.276$. The PDI was about 0.2 and no significant change in Zeta potential. The average Nano size measured by TEM was $30 \pm 15$. Indicating stable CSNPs carriers especially stored at low temperature. Six month tested loaded formula showed average Nano size measured by TEM was $49.7 \pm 4.8$, average size measured by Zeta sizer was $224.633 \pm 18$, PDI was $0.349 \pm 0.04$, Zeta potential was $19.516 \pm 3.3$, mean $\mathrm{EE} \%$ was $94.674 \pm 1.4$, drug loading was $43.061 \pm 0.6$ and drug retention value $\%$ of six month storage was $97.605 \pm 1.7$. These results emphasize that either plane or loaded CSNPs carriers are fairly stable over six month stability studies.

\section{Antibacterial activity}

Chitosan has been identified as an antimicrobial agent against various microorganisms [48]. CSNPs have gained growing interest due to its biocompatibility, biodegradability, high permeability, costeffectiveness, non-toxic property and excellent film forming ability. Moreover, its ability to enhance the penetration of large molecules across a mucosal surface and its recognition as mucoadhesive agent $[49,50]$. However, the evaluation of CSNPs antibacterial activity has rarely been reported. The unique character of CSNPs i.e. very small quantum size exhibit them superior activities [51]. In the present study the antibacterial activity CSNPs $(1250 \mu \mathrm{g} / \mathrm{ml})$ and cephalexin loaded CSNPs $(250 \mu \mathrm{g} / \mathrm{ml}$ cephalexin loaded in $1250 \mu \mathrm{g} / \mathrm{ml}$ CSNPs) was evaluated and compared to a reference; cephalexin antibiotic $(1000 \mu \mathrm{g} / \mathrm{ml})$ by microdilution method (table 6) against different Gram-positive and Gram-negative bacterial strains. Both CSNPs and cephalexin loaded CSNPs showed good antimicrobial activity against Gram-positive and Gram negative bacteria. However cephalexin loaded CSNPs showed higher antimicrobial activity than plain CSNPs. Nevertheless, it is worth pointing out that synergistic effects were found against S. aureus (ATCC 25923), B. subtilis (ATCC 9372), $S$. epidermidis and E. faecalis. MIC of Cephalexin in CSNPs combination was $31.25,3.9,3.9$ and $31.25 \mu \mathrm{g} / \mathrm{ml}$ respectively. There was a great reduction in MIC values for cephalexin loaded CSNPs compared to plain Cephalexin. Additionally cephalexin loaded CSNPs showed higher bactericidal activity against $S$. epidermidis $(78.5 \mu \mathrm{g} / \mathrm{ml})$ and $312.5 \mu \mathrm{g} / \mathrm{ml}$ for other Gram positive strains. These results were comparable to a many studies that comparing the activity of plain chitosan nanoparticle to antibiotics loaded nanoparticles. A study by Saha et al. [52], demonstrated superior antimicrobial activity and synergistic effect of ampicillin trihydrate loaded chitosan nanoparticles compared to both plain nanoparticles and reference antibiotics. Moreover $\mathrm{Xu}$ et al. [53]. Prepare vancomycin loaded chitosan nanoparticles that displayed a lower MIC value than plain vancomycin (80 to $60 \mu \mathrm{g} / \mathrm{ml}$ ) against $S$. aureus that corresponds to higher antibacterial effectiveness. In the same line Ibrahim et al. [54], in Egypt prepare chitosan nanoparticles to improve intracellular delivery of some poorly cell-penetrating antibiotic e. g. Ciprofloxacin, Chlortetracycline hydrochloride and
Gentamycin sulfate and reported an increase in antibacterial activity of loaded chitosan nanoparticles against Gram-positive ( $S$. aureus) bacteria rather than Gram-negative (E. coli) bacteria. In the current study plain CSNPs found to have antibacterial inhibitory effect against S. aureus (ATCC 25923) (MIC, 312.5) and E. faecalis (MIC, 312.5 better than the reference antibiotic (MIC $>500$ ). This result was comparable to Thaya, et al. [55], who reported that chitosanalginate microspheres exhibited effective growth inhibition against S. aureus, E. faecalis more than P. aeruginosa and Proteus vulgaris by disk diffusion method.

Regarding the effectiveness of both formulas against Gram-negative bacterial strains; cephalexin loaded CSNPs displayed synergistic effects against $P$. aeruginosa (ATCC 29853) and against two carbapenem resistant isoletes ( $k$. pneumoniae and E. coli clinical isolates); MIC values were $31.25,3.9$ and $31.25 \mu \mathrm{g} / \mathrm{ml}$ respectively which is also far different compared to plain Cephalexin. On the other hand antagonistic effect was found against E. coli (ATCC 25922). The MIC of cephalexin loaded CSNPs against E. coli (ATCC 25922) was $31.25 \mu \mathrm{g} / \mathrm{ml}$ while it was $15.625 \mu \mathrm{g} / \mathrm{ml}$ for plain cephalexin which indicated antagonism. The MBC value of cephalexin loaded CSNPs was $312.5 \mu \mathrm{g} / \mathrm{ml}$ for all Gram negative bacteria except E. coli (ATCC 25922) was $625 \mu \mathrm{g} / \mathrm{ml}$. These results were consistent with various recent studies such as Kanchana et al. [56], whose antibacterial activity results demonstrates a lower MIC values for antibiotics (ampicillin trihydrate and cephalexin) encapsulated chitosan nanoparticles than pare antibiotics against Escherichia coli and Klebsiella pneumoniae causing urinary tract infection. Also Plain CSNPs displayed antibacterial inhibitory effect against E. coli and Pseudomonas aeruginosa (MIC, 312.5 and 312.5 respectively) better than the reference antibiotic (MIC, $>500$ ). Our results agreed with Divya et al. [57], who reported high antimicrobial activity of chitosan nanoparticles $(5000 \mu \mathrm{g} / \mathrm{ml})$ against medical pathogens Klebsiella pneumoniae, Escherichia coli, Staphylococcus aureus and Pseudomonas aeruginosa. Furthermore Tamara et al. [58], indicated that the chitosan/protamine nanoparticles have improved antibacterial activity towards pathogenic E. coli rather than probiotic B. cereus.

Conversely, a relatively poor antibacterial activity shown for $E$. coli (ATCC 25922) may be related to decreased charge compactness, which established with the surface charge classification of 'slightly charged' [59]. Generally, the antimicrobial effectiveness of chitosan against Gram-positive and Gram-negative bacteria is fairly contentious. In some published works, a predominant effectiveness against Gram-positive strains is documented. Although the interaction between positively charged chitosan groups and negatively charged microbial cell is assumed as the main antimicrobial mechanism $[60,61]$, the thick peptidoglycan layer provide a barrier against chitosan interactions. While the Gramnegative cell wall is thinner and consequently more susceptible to chitosan derivatives than the Gram-positive's bacterial strains [62, 63]. Positively charged chitosan easily interfere with negatively charged bacterial cell membrane that is may be the hopeful mechanism for the bactericidal characters [55].

Table 6: MIC and MBC of cephalexin, CSNPs, and cephalexin loaded CSNPs against different microorganisms

\begin{tabular}{|c|c|c|c|c|c|c|c|}
\hline \multirow{2}{*}{$\begin{array}{l}\text { M. O } \\
\text { Gram-positive bacteria }\end{array}$} & \multicolumn{2}{|c|}{ Cephalexin $(\mu \mathrm{g} / \mathrm{ml})$} & \multicolumn{2}{|c|}{ CSNPs $(\mu \mathrm{g} / \mathrm{ml})$} & \multicolumn{2}{|c|}{ Cephalexin $(\mu \mathrm{g} / \mathrm{ml})$ loaded in CSNPs } & \multirow[t]{2}{*}{$\Sigma$ FIC } \\
\hline & MIC & MBC & MIC & MBC & MIC & MBC & \\
\hline S. aureus (ATCC 25923) & $>500$ & $>500$ & 312.5 & 625 & 31.25 & 312.5 & 0.562 Synergism \\
\hline B. subtilis (ATCC 9372) & 15.625 & 500 & 156.25 & 625 & 3.9 & 312.5 & 0.37 Synergism \\
\hline S. epidermidis & 62.5 & 500 & 78.5 & 156.25 & 3.9 & 78.5 & 0.311 Synergism \\
\hline E. faecalis & $>500$ & $>500$ & 312.5 & 625 & 31.25 & 312.5 & 0.562 Synergism \\
\hline \multicolumn{8}{|l|}{ Gram-negative bacteria } \\
\hline E. coli (ATCC 25922). & 15.625 & 125 & 312.5 & 625 & 31.25 & 625 & 2.18 Antagonism \\
\hline $\begin{array}{l}\text { P. aeruginosa (ATCC } \\
\text { 29853). }\end{array}$ & $>500$ & $>500$ & 312.5 & 625 & 31.25 & 312.5 & 0.562 Synergism \\
\hline k. pneumoniae & 15.625 & 250 & 156.25 & 625 & 3.9 & 312.5 & 0.37 Synergism \\
\hline E. coli & $>500$ & $>500$ & 312.5 & $>625$ & 31.25 & 312.5 & 0.562 Synergism \\
\hline
\end{tabular}

\section{Biofilm inhibition assay}

Pathogenic microorganisms produce biofilm by synthesizing exopolysaccharides which enable bacterial adhering to the surfaces and protects the microbes from the harsh environment [64]. Biofilm producers microorganisms are the major cause of prosthetic device related infections. Though it is a major medical problem, much work has not been performed in this respect [65]. Most of the research 
studies focusing on action of chitosan against planktonic microorganisms, but restricted information is known about its activity upon bacterial adhesion and biofilm formation [69]. In current work; screening of biofilm production of tested microorganisms by culturing onto CRA plate (Fig: 7a) revealed that two multidrug resistant clinical isolates (klebsiella pneumoniae and Enterococcus faecalis) were biofilm producers, accordingly, the antibiofilm activity of CSNPs and cephalexin loaded CSNPs in their sub MIC conc. were tested against both microorganisms by tube assay. Results showed that cephalexin loaded in CSNPs displayed antibiofilm activity in its sub MIC concentration ( $62.5 \mu \mathrm{g} / \mathrm{ml})$ against Enterococcus faecalis (Fig: $7 \mathrm{~b})$ and no antibiofilm activity was detected against klebsiella pneumoniae clinical isolate in sub MIC $(7.8 \mu \mathrm{g} / \mathrm{ml})$ of cephalexin loaded in CSNPs. These results were agreed with study by Thaya, et al. [55], who reported that chitosan-alginate microspheres exhibited antibiofilm effect against $S$. aureus, E. faecalis $P$. aeruginosa and $P$. vulgaris respectively, also another study by Costa et al. [66], investigated the antibiofilm activity of chitosan on periodontal bacteria and both studies showed that chitosan has antibiofilm activity with high inhibition rate against specified pathogens. Moreover Divya and Jisha [64], investigated the antibiofilm activity of chitosan nanoparticles against $K$. pneumoniae, E. coli, $S$. aureus, $P$. aeruginosa clinical isolates. This antibiofilm activity could be correlated to inhibition of exopolysaccharide synthesis resulting in reduction of biofilm formation [67]. Also the aforementioned activity may be associated with the diffusion of nanoparticles through the channels in biofilm structure [68].

\section{MTT cytotoxicity assay}

The MTT assay measures the cell metabolic activity, which is directly proportional to cell numbers under appropriate culture conditions. The percentages of viable cells were determined in relation to the control cells fig. (8). Cytotoxic effects of CSNPs and cephalexin loaded CSNPs on WI-38 fibroblasts cells proliferation, viability and IC50 were carried out by MTT cytotoxicity assay (table 7). The results revealed that cephalexin loaded CSNPs has lower cytotoxicity compared to plain CSNPs. The half maximal inhibitory concentration (IC50 which is defined as the drug concentration needed to kill $50 \%$ of the incubated cells in a specific time) of cephalexin loaded CSNPs was 231.893 while for CSNPs IC50 was 18.597 . The viability of cells was $99.25 \%$ and 38.2 $\%$ at $23.4(3.9+19.53) \mu \mathrm{g} / \mathrm{ml}$ conc. of cephalexin loaded CSNPs and CSNPs respectively. Fig. ( 9 and 10). These results were in agreement with previous studies as a study by Xu et al. [53], where VancomycinLoaded N-trimethyl chitosan nanoparticle showed significantly higher cell proliferation activity compared with vancomycin solutions. Also Hussein et al. [38], reported that the highest concentrations of plain drug and drug loaded-CSNPs $(100 \mu \mathrm{g} / \mathrm{ml})$ resulted in 78.2 and $62.4 \%$ cells viability, respectively. This proliferative effect is complemented by nanostructure, biocompatibility and fixed surface structure in the nanometer size scale [69]. On the other hand, Salarian et al. [70], perform MTT assay for cephalexin alone at different concentrations and no cytotoxicity was detected even at a high concentration of 5000 $\mathrm{mg} / \mathrm{ml}$ confirming that highly concentrated non-toxic cephalexin could be applied as effective treatment even at higher dosages.

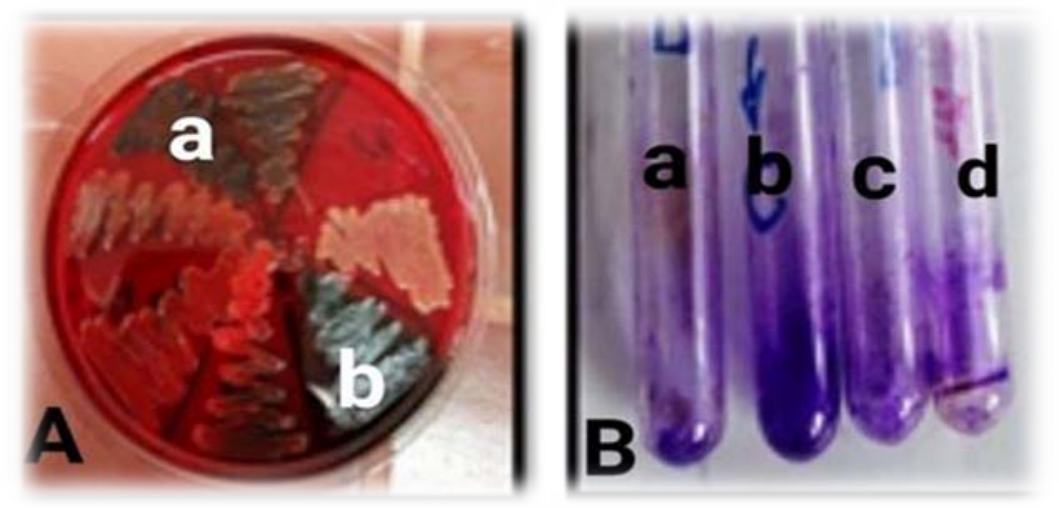

Fig. 7A: CRA plates showed black dry crystalline colonies of Enterococcus faecalis (a) and klebsiella pneumoniae(b), B: biofilm tube assay for Enterococcus faecalis (a): negative control, (b): positive control, (c): CSNPs and (d): cephalexin loaded CSNPs

Table 7: MTT cytotoxicity assay profile showing Viability \%, toxicity \% and IC50 of control, CSNPs and cephalexin loaded CSNPs. The percentages of viable cells were expressed relative to the control cells (WI-38 fibroblasts)

\begin{tabular}{|c|c|c|c|c|c|c|c|c|c|}
\hline \multirow{2}{*}{$\begin{array}{l}\text { ID } \\
W i-38\end{array}$} & \multirow[t]{2}{*}{ Conc. $\mu \mathrm{g} / \mathrm{ml}$} & \multicolumn{3}{|c|}{ Optical density (OD) } & \multirow{2}{*}{$\begin{array}{l}\text { Mean OD } \\
0.259\end{array}$} & \multirow{2}{*}{$\begin{array}{l}\text { STD } \\
0.002517\end{array}$} & \multirow{2}{*}{$\begin{array}{l}\text { Viability \% } \\
100\end{array}$} & \multirow{2}{*}{$\begin{array}{l}\text { Toxicity \% } \\
0\end{array}$} & \multirow[t]{2}{*}{ IC50 } \\
\hline & & 0.256 & 0.264 & 0.257 & & & & & \\
\hline & 750 & 0.016 & 0.024 & 0.018 & 0.019333 & 0.002404 & 7.464607465 & 92.53539254 & \\
\hline \multirow[t]{7}{*}{ CSNPs } & 375 & 0.026 & 0.031 & 0.025 & 0.027333 & 0.001856 & 10.55341055 & 89.44658945 & 18.597 \\
\hline & 187.5 & 0.053 & 0.06 & 0.058 & 0.057 & 0.002082 & 22.00772201 & 77.99227799 & \\
\hline & 93.75 & 0.06 & 0.077 & 0.071 & 0.069333 & 0.004978 & 26.76962677 & 73.23037323 & \\
\hline & 46.875 & 0.094 & 0.088 & 0.087 & 0.089667 & 0.002186 & 34.62033462 & 65.37966538 & \\
\hline & 23.438 & 0.1 & 0.099 & 0.098 & 0.099 & 0.000577 & 38.22393822 & 61.77606178 & \\
\hline & 11.718 & 0.175 & 0.156 & 0.158 & 0.163 & 0.006028 & 62.93436293 & 37.06563707 & \\
\hline & 5.859 & 0.236 & 0.242 & 0.238 & 0.238667 & 0.001764 & 92.14929215 & 7.850707851 & \\
\hline \multirow{12}{*}{$\begin{array}{l}\text { Cephalexin } \\
\text { loaded CSNPs }\end{array}$} & 750 & 0.026 & 0.035 & 0.024 & 0.028333 & 0.003383 & 10.93951094 & 89.06048906 & 231.893 \\
\hline & $125+625$ & & & & & & & & \\
\hline & 375 & 0.052 & 0.064 & 0.059 & 0.058333 & 0.00348 & 22.52252252 & 77.47747748 & \\
\hline & $62.5+312.5$ & & & & & & & & \\
\hline & 187.5 & 0.124 & 0.133 & 0.128 & 0.128333 & 0.002603 & 49.54954955 & 50.45045045 & \\
\hline & $31.25+156.25$ & & & & & & & & \\
\hline & 93.75 & 0.205 & 0.216 & 0.209 & 0.21 & 0.003215 & 81.08108108 & 18.91891892 & \\
\hline & $15.6+78.125$ & & & & & & & & \\
\hline & 46.8 & 0.241 & 0.25 & 0.246 & 0.245667 & 0.002603 & 94.85199485 & 5.148005148 & \\
\hline & $7.8+39.06$ & & & & & & & & \\
\hline & 23.46 & 0.254 & 0.256 & 0.261 & 0.257 & 0.002082 & 99.22779923 & 0.772200772 & \\
\hline & $3.9+19.53$ & & & & & & & & \\
\hline
\end{tabular}

The results are presented as mean $\pm \mathrm{SD}$ 


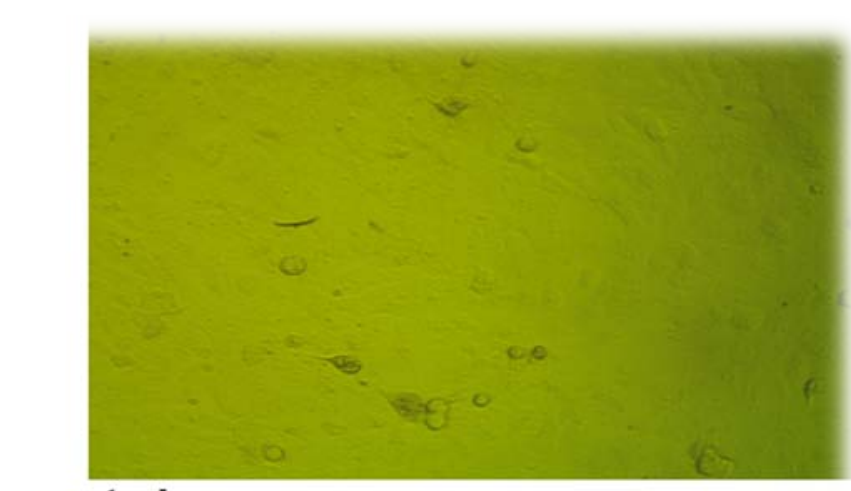

\section{control}

WI-38cells

Fig. 8: Adherent, normal WI-38 fibroblast control cells
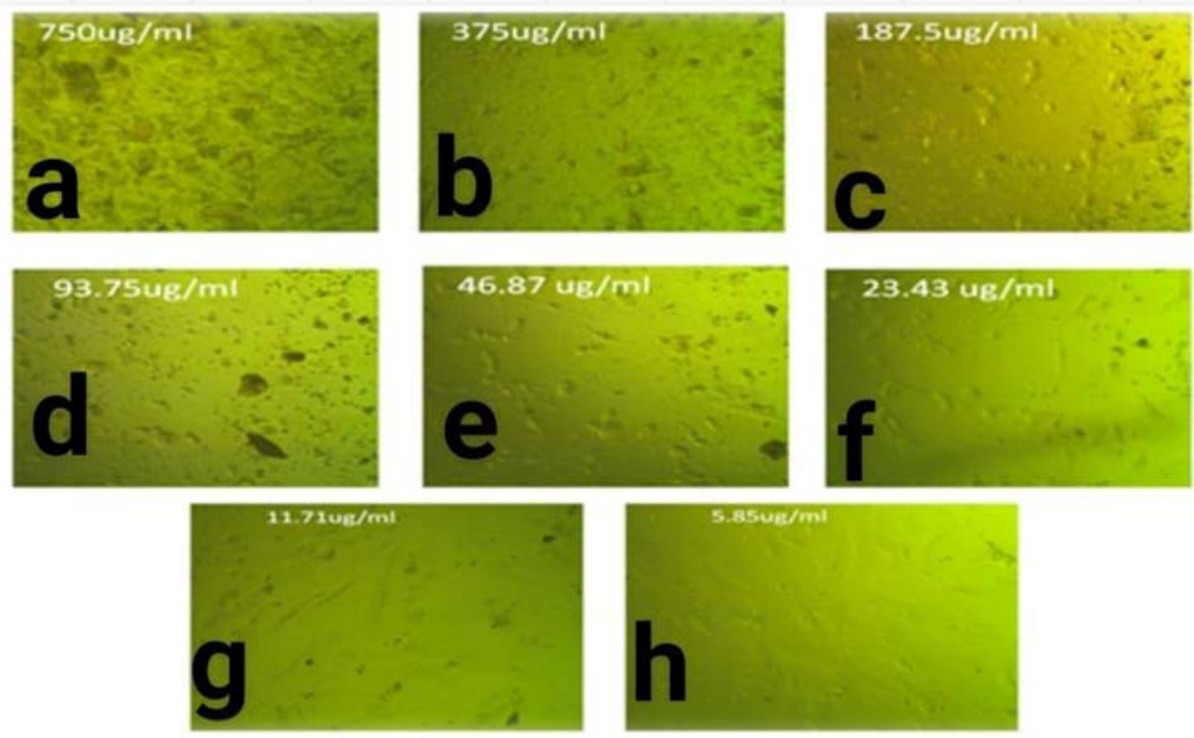

A

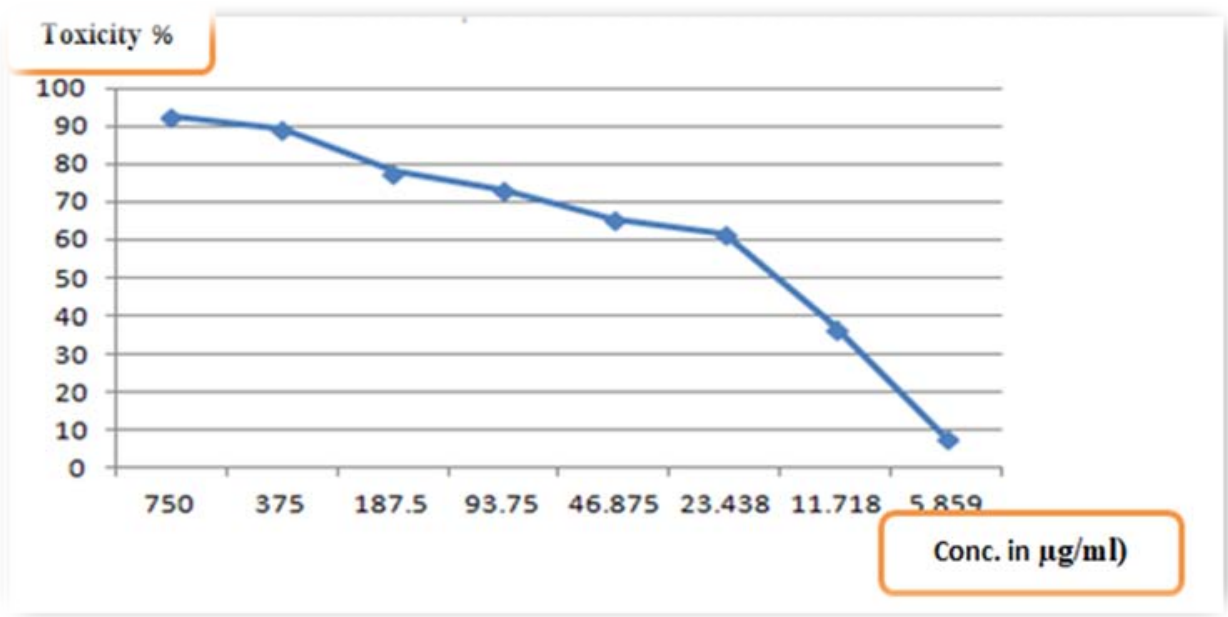

B

Fig. 9(A and B): Toxicity effect of CSNPs on WI-38 cells at different concentrations 

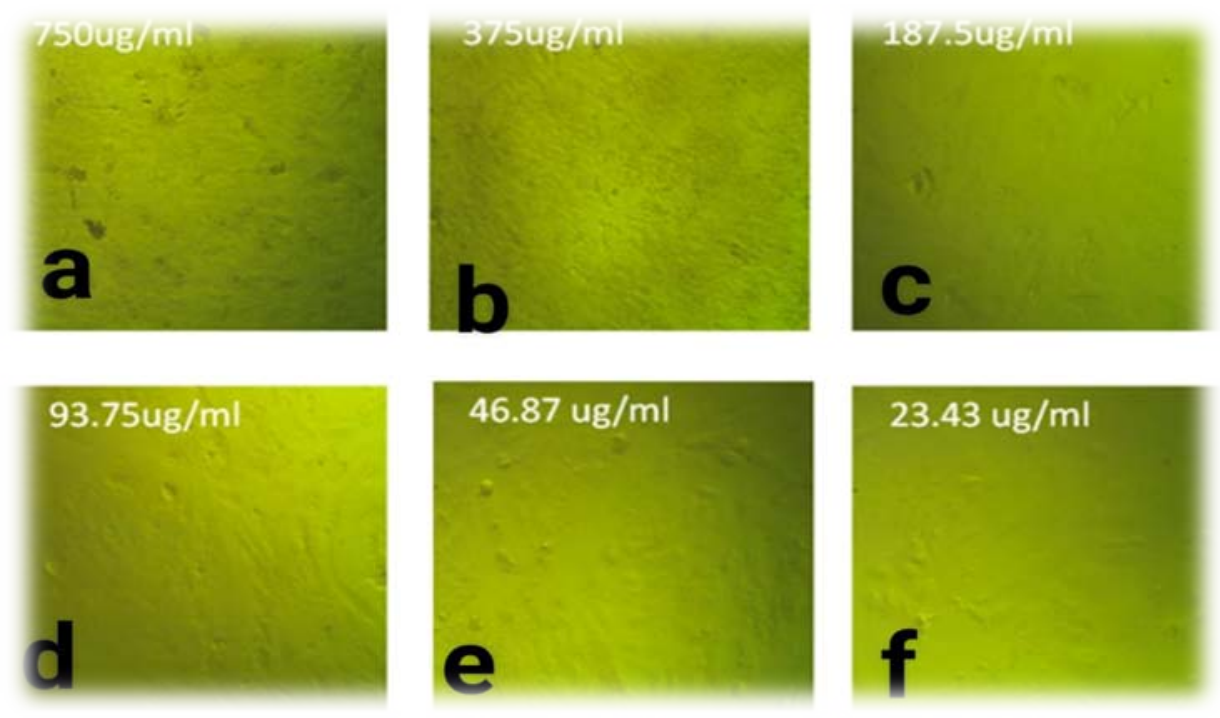

A

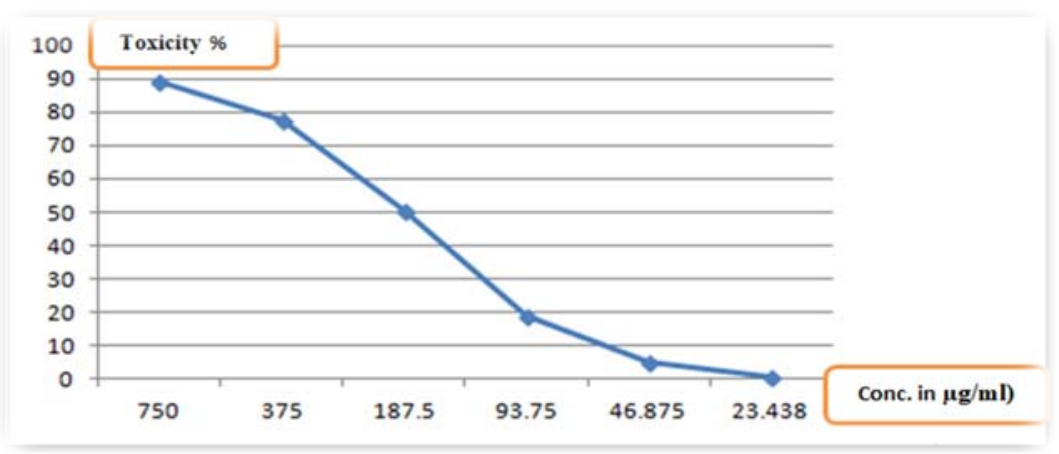

Fig. 10(A, B): Toxicity effect of cephalexin loaded CSNPs on WI-38 cells at different concentrations

\section{CONCLOSION}

Cephalexin-chitosan nanocomposites were successfully prepared with simple method and good combination. Nano-particles criteria were suitable in addition to drug loaded and release. Formulas proved long term stabilityCephalexin loaded CSNPs showed synergistic effects against seven of studied bacterial strains including two carbapenem resistant isolates. Also it exhibit antibiofilm activity against $E$. faecalis clinical isolate and had minimized cytotoxicity.

\section{ACKNOWLEDGEMENT}

The authors are thankful for Simco Shefa pharmaceutical Company for giving cephalexin gift, also the research labs in each of Future and Al-Azhar University.

\section{AUTHORS CONTRIBUTIONS}

All authors had equally contributed the research work.

\section{CONFLICT OF INTERESTS}

All authors have none to declare

\section{REFERENCES}

1. Raffi, Muhammad. Investigations into the antibacterial behavior of copper nanoparticles against Escherichia coli. Ann Microbiol 2010;60(Suppl 1):75-80.

2. Zaki NM, Hafez MM. Enhanced antibacterial effect of ceftriaxone sodium-loaded chitosan nanoparticles against intracellular Salmonella typhimurium. AAPS PharmSciTech 2012;13(Suppl 2):411-21.
3. Chattopadhyay D, Inamdar M. Improvement in properties of cotton fabric through synthesized nano-chitosan application. Indian J Fibre Textil Res 2013;38:14-21.

4. Benhabiles M, Salah R, Lounici H, Drouiche N, Goosen M, Mameri N. Antibacterial activity of chitin, chitosan and its oligomers prepared from shrimp shell waste. Food Hydrocolloids 2012;29(Suppl 1):48-56.

5. Cruz Romero M, Murphy T, Morris M, Cummins E, Kerry J. Antimicrobial activity of chitosan, organic acids and nano-sized solubilisates for potential use in smart antimicrobially-active packaging for potential food applications. Food Control 2013;34(Suppl 2):393-7.

6. Nagy A, Harrison A, Sabbani S, Munson JrRS, Dutta PK, Waldman WJ. Silver nanoparticles embedded in zeolite membranes: release of silver ions and mechanism of antibacterial action. Int J Nanomed 2011;6:1833-52.

7. Cuero R, Osuji G, Washington A. Carboxymethyl chitosan inhibition of aflatoxin production: role of zinc. Biotechnol Lett 1991;13:441-4.

8. Jimtaisong A, Saewan N. Utilization of carboxymethyl chitosan in cosmetics. Int J Cosmetic Sci 2014;36(Suppl 1):12-21.

9. El-Sherbiny IM, El-Baz NM. A review on bio nanocomposites based on chitosan and its derivatives for biomedical applications, eco-friendly polymer nanocomposites. Chem Appl 2015;74-173. Doi: 10.1007/978-81-322-2473-0_6

10. GOY Rejane C, BRITTO Douglas de ASSIS, Odilio BG. A review of the antimicrobial activity of chitosan. Polimeros 2009;19(Suppl 3):241-7.

11. Jia Z, Xu W. Synthesis and antibacterial activities of quaternary ammonium salt of chitosan. Carbohydr Res 2001;333(Suppl 1):1-6. 
12. Lu Y, Cheng D, Lu S, Huang F, Li G. Preparation of quaternary ammonium salt of chitosan nanoparticles and their textile properties on antheraea pernyi silk modification. Textile Res J 2014;84(Suppl 19):2115-24.

13. Chung YC, Su YP, Chen CC, Jia G, Wang HL, Wu JCG, et al. Relationship between antibacterial activity of chitosan and surface characteristics of cell wall. Acta Pharmacol Sin 2004;25(Suppl 7):932-6.

14. Van der Lubben I, Verhoef J, Borchard G, Junginger H. Chitosan for mucosal vaccination. Adv Drug Delivery Rev 2001;52(Suppl 2):139-44.

15. Sawaengsak C, Mori Y, Yamanishi K, Mitrevej A, Sinchaipanid N. Chitosan nanoparticle encapsulated hemagglutinin-split influenza virus mucosal vaccine. AAPS PharmSciTech 2014;15(Suppl 2):317-25.

16. Del Guidice G, Baudner B. Mucosal vaccines with chitosan adjuvant and meningococcal antigens; 2015.

17. Avadi M, Sadeghi A, Tahzibi A, Bayati K, Pouladzadeh M, Zohuriaan-Mehr $\mathrm{M}$, et al. Diethylmethyl chitosan as an antimicrobial agent: Synthesis, characterization and antibacterial effects. Eur Polym J 2004;40(Suppl 7):1355-61.

18. Abdel Fattah WI, Sallam ASM, Attawa N, Salama E, Maghraby AM, Ali GW. Functionality, antibacterial efficiency and biocompatibility of nanosilver/chitosan/silk/phosphate scaffolds 1. Synthesis and optimization of nanosilver/chitosan matrices through gamma rays irradiation and their antibacterial activity. Mater Res Express 2012;1(Suppl 3):35-24.

19. Garrait G, Beyssac E, Subirade M. Development of a novel drug delivery system: chitosan nanoparticles entrapped in alginate microparticles. J Microencapsulation 2014;31(Suppl 4):363-72.

20. TiyaboonchaI W. Chitosan nanoparticles: a promising system for drug delivery. Naresuan University J 2003;11(Suppl3):51-66.

21. Kim TH, Park IK, Nah JW, Choi YJ, Cho CS. Galactosylated chitosan/DNA nanoparticles prepared using water-soluble chitosan as a gene carrier. Biomaterials 2004;25(Suppl 17):3783-92.

22. Chaisri W, Hennink WE, Okonogi S. Preparation and characterization of cephalexin loaded PLGA microspheres. Curr Drug Delivery 2009;6:69-75.

23. Speight TM, Brogden RN, Avery GS. Cephalexin: a review of its antibacterial, pharmacological and therapeutic properties. Drugs 1972;3:9-78.

24. El Menofy NG. Phenotypic and molecular detection of new delhi metallo-betalactamase-1 (bla NDM-1) gene among Escherichia coli and Klebsiella pneumoniae in hospitalized Egyptian patients. New Egypt J Microbiol 2018;51:1-14.

25. El-Assal MIA. Proniosomes as nano-carrier for transdermal delivery of atenolol niosomal gel. Int J Drug Delivery Technol 2017;7:283-97.

26. Yasmin MB, Prathyusha RG. Formulation and evaluation of dasatinib loaded solid lipid nanoparticles. Int J Pharm Pharm Sci 2018;10:14-20.

27. $\mathrm{Hu}$ CJ, Rhodes DG. Proniosomes: a novel drug carrier preparation. Int J Pharm 1999;185:23-35.

28. Yadav SK. Nanoscale materials in targeted drug delivery. Theragnosis and Tissue Regeneration. New York: Springer; 2016.

29. Al Kassas RS, Al Gohary OM, Al Faadhel MM. Controlling of systemic absorption of gliclazide through incorporation into alginate beads. Int J Pharm 2007;341:230-7.

30. Shweta P. Formulation and evaluation of garlic powder loaded floating matrix tablet. Int J Pharm Pharm Sci 2019;11:17-21.

31. Shu XZ, Zhu KJ, Song W. Controlled drug release properties of ionically cross-linked chitosan beads: the influence of anion structure. Int J Pharm 2002;233:217-25.

32. Pourjavadi A, Barzegar Sh, GR Mahdavinia. MBA-crosslinked $\mathrm{Na}-\mathrm{Alg} / \mathrm{CMC}$ as a smart full-polysaccharide superabsorbent hydrogels. Carbohydr Polym 2006;66:386-95.

33. Pardakhty A, Varshosaz J, Rouholamini A. In vitro study of polyoxyethylene alkyl ether niosomes for delivery of insulin. Int J Pharm 2007;328:130-41.

34. Novy P, Davidova H, Serrano Rojero CS, Rondevaldova J, Pulkrabek Kokoska. Composition and antimicrobial activity of Euphrasia rostkoviana Hayne essential oil. J Evidence Based
Complementary Altern Med 2015:5.http://dx.doi.org/ 10.1155/ 2015/734101

35. Jamaran S, Zarif BR. Synergistic effect of silver nanoparticles with neomycin or gentamicin antibiotics on mastitis-causing Staphylococcus aureus. Open J Ecol 2016;6(Suppl 7):452.

36. Fratini F. A novel interpretation of the fractional inhibitory concentration index: the case origanum vulgare $L$. and leptospermum scoparium JR et G. Forst essential oils against Staphylococcus aureus strains. Microbiol Res 2017;195:11-7.

37. Hasan Y, Ozeki, SR Kabir. Purification of a novel chitin-binding lectin with antimicrobial and antibiofilm activities from a Bangladeshi cultivar of potato (Solanum tuberosum). Indian J Biochem Biophysics 2014;51(Suppl 2):142-8.

38. Hussein Al Ali, Samer Hasan. Preparation of chitosan nanoparticles as a drug delivery system for perindopril erbumine. Polymer Composites 2018;39(Suppl 2): 544-52.

39. Kittur FS, Harish Prashanth KV, Udaya Sankar K, Tharanathan RN. Characterization of chitin, chitosan and their carboxymethyl derivatives by differential scanning calorimetry. Carbohydrate Polymers 2002;49:185-93.

40. Di Stefano R, Scopelliti M, Pellerito C, Casella G, Fiore T, Stocco $\mathrm{GC}$, et al. Organometallic complexes with biological molecules. XVIII. Alkyltin (IV) cephalexinate complexes: synthesis, solid state and solution phase investigations. J Inorg Biochem 2004;98(Suppl 3):534-46.

41. $\mathrm{Xu} \mathrm{WZ,} \mathrm{Wang} \mathrm{SQ,} \mathrm{Li} \mathrm{AJ,} \mathrm{Wang} \mathrm{XL.} \mathrm{Synthesis} \mathrm{of}$ aminopropyltriethoxysilane grafted/tripolyphosphate intercalated $\mathrm{ZnAl} \mathrm{LDHs}$ and their performance in the flame retardancy and smoke suppression of polyurethane elastomer. RSC Adv 2016;6:48189-98.

42. $\mathrm{Xu} \mathrm{Y,} \mathrm{Du} \mathrm{Y.} \mathrm{Effect} \mathrm{of} \mathrm{molecular} \mathrm{structure} \mathrm{of} \mathrm{chitosan} \mathrm{on} \mathrm{protein}$ delivery properties of chitosan nanoparticles. Int J Pharm 2003;250:215-26.

43. Knaul JZ, Hudson SM, Creber KAM. Improved mechanical properties of chitosan fibres. J Appl Polym Sci 1999;72:1721-31.

44. Wang X, Ma J, Wang Y, He B. Structural characterization of phosphorylated chitosan and their applications as effective additives of calcium phosphate cements. Biomaterials 2001;22:2247-55.

45. Noyes A, Itney W. The rate of solution of solid substances in their own solutions. J Am Chem Soc 1897;19:934.

46. Higuchi T. Mechanism of sustained-action medication theoretical analysis of release of solid drugs dispersed in solid matrices. J Pharm Sci 1963;52:1145-9.

47. Macheras P, Dokoumetzidis A. On the heterogeneity of drug dissolution and release. Pharm Res 2000;17:108-12.

48. Friedman M, Juneja VK. Review of antimicrobial and antioxidative activities of chitosans in food. J Food Prot 2010;73(Suppl 9):1737-61.

49. Ghadi A, Mahjoub S, Tabandeh F, Talebnia F. Synthesis and optimization of Chitosan nanoparticles: potential applications in nanomedicine and biomedical engineering. Iran Caspian: J Intern Med 2014;5(Suppl 3):156-61.

50. Saini R, Saini S, Sharma S. Nanotechnology: the future medicine. J Cutan Aesthet Surg 2010;3(Suppl 1):32-3.

51. Wardani Giftania. In vitro antibacterial activity of chitosan nanoparticles against mycobacterium tuberculosis. Pharmacogn J 2018;10(Suppl 1):162-6.

52. Saha P, Goyal AK, Rath G. Formulation and evaluation of chitosan-based ampicillin trihydrate nanoparticles. Trop J Pharm Res 2010;9:483-8.

53. Xu J, Xu B, Shou D, Xia X, Hu Y. Preparation and evaluation of vancomycin-loaded N-trimethyl chitosan nanoparticles. Polymers 2015;7(Suppl 9):1850-70.

54. Ibrahim HM, El-Bisi MK, Taha GM, El-Alfy EA. Chitosan nanoparticles loaded antibiotics as drug delivery biomaterial. J Appl Pharm Sci 2015;5(Suppl 10):85-90.

55. Thaya Rajagopalan. Synthesis of chitosan-alginate microspheres with high antimicrobial and antibiofilm activity against multi-drug resistant microbial pathogens. Microbial Pathogenesis 2018;114:17-24.

56. Kanchana M, Malathy BR, Jeevitha D, Reema O, Sonia S. Synthesis and evaluation of amoxicillin and cephalexin encapsulated chitosan nanoparticles against urinary tract 
infection causing Escherichia coli and Klebsiella pneumoniae. World J Pharm Res 2014;3(Suppl 2):512-26.

57. Divya K, Vijayan S, George TK, Jisha MS. Antimicrobial properties of chitosan nanoparticles: mode of action and factors affecting activity. Fibers Polymers 2017;18(Suppl 2):221-30.

58. Tamara F, Lin C, Mi FL, Ho YC. Antibacterial effects of chitosan/cationic peptide nanoparticles. Nanomaterials 2018;8(Suppl 2):88.

59. Li J, McL, Sborough L. The effects of the surface charge and hydrophobicity of Escherichia coli on its adhesion to beef muscle. Int J Food Microbiol 1999;53:185-93.

60. Rabea EI, Badawy ME, Stevens CV, Smagghe G, Steurbaut W. Chitosanas antimicrobial agent: applications and mode of action. Bio Macromolecules 2003;4:1457-65.

61. Divya K, Jisha MS. Chitosan nanoparticles preparation and applications. Environ Chem Lett 2018;16:101-12.

62. Zheng LY, Zhu JF. Study on antimicrobial activity of chitosan with different molecular weights. Carbohydr Polym 2003;54:527-630.

63. Goy RC, Morais ST, Assis OB. Evaluation of the antimicrobial activity of chitosan and its quaternized derivative on E. coli and S. aureus growth. Rev Bras Farmacogn 2016;26(Suppl 1):122-7.
64. Ramachandran R, Sangeetha D. Antibiofilm efficacy of silver nanoparticles against biofilm forming multidrug resistant clinical isolates. Pharma Innovation 2017;6(11, Part A):36.

65. Hassan A, Usman J, Kaleem F, Omair M, Khalid A, Iqbal M. Evaluation of different detection methods of biofilm formation in the clinical isolates. Braz J Infect Dis 2011;15(Suppl 4):305-11.

66. Costa EM, Silva S, Pina C, Tavaria FK, Pintado M. Antimicrobial effect of chitosan against periodontal pathogens biofilms. SOJ Microbiol Infect Dis 2014;2(Suppl 1):1-6.

67. Namasivayam SKR, Roy EA. Enhanced antibiofilm activity of chitosan stabilized chemogenic silver nanoparticles against Escherichia coli. Int J Sci Res Publications 2013;3(Suppl 4):1-9.

68. Kalishwaralal K, Barath Mani Kanth S, Pandian SRK, Deepak V, Gurunathan S. Silver nanoparticles impede the biofilm formation by Pseudomonas aeruginosa and Staphylococcus epidermidis: Colloids Surf B 2010;79(Suppl 2):340-4

69. Yeon SJ, Lee JW, Lee JW, Kwark YJ, Kim SH, Lee KY. Effect of nano-structured polymer surfaces on osteoblast adhesion and proliferation. J Controlled Release 2011;152:e257-58.

70. Salarian AA, Mollamahale YB, Hami Z, Soltani Rezaee Rad M. Cephalexin nanoparticles: synthesis, cytotoxicity and their synergistic antibacterial study in combination with silver nanoparticles. Materials Chem Physics 2017;198:125-30. 